This PDF is a selection from an out-of-print volume from the National Bureau of Economic Research

Volume Title: The Statistical Pattern of Instalment Debt

Volume Author/Editor: Ralph A. Young and Blanche Bernstein

Volume Publisher: NBER

Volume URL: http://www.nber.org/books/youn39-1

Publication Date: 1939

Chapter Title: The Statistical Pattern of Instalment Debt

Chapter Author: Ralph A. Young, Blanche Bernstein

Chapter URL: http://www.nber.org/chapters/c5223

Chapter pages in book: (p. 1 - 23) 
A NON-PROFIT MEMBERSHIP CORPORATION FOR IMPARTIAL STUDIES IN ECONOMIC AND SOCIAL SCIENCE

\begin{tabular}{lcc}
\hline Bulletin $76-7$ & 1819 BROADWAY, NEW Y ORK & October 25, 2939 \\
\hline Copyright, 1939, National Bureau of Economic Research, Inc.
\end{tabular}

\section{THE STATISTICAL PATTERN OF INSTALMENT DEBT}

\section{R. A. Young and Blanche Bernstein}

T his Bulletin presents findings developed from a study of the use of instalment credit for the purchase of commodities. The study was initiated in 1938 as one phase of the National Bureau's investigation of consumer instalment financing, the first project under the program of research in finance supported by special grants from the Association of Reserve City Bankers and the Rockefeller Foundation. Other results of the study will be published later in 1939.

The preparation of the study was directed by Ralph $A$. Young, and the estimates of the use of instalment credit were made by Blanche Bernstein. Dr. Young and Miss Bernstein collaborated in writing the text.

The authors wish to acknowledge the statistical assistance of Pauline Arkus, Peter Franck, and Esther Skala. For criticism of our first draft we are indebted to Moses Abramovitz, B. H. Beckhart, Milton Friedman, Gottfried Haberler, Simon Kuznets, F. C. Mills, WT. W. Riefler, and Leo Wolman. Mr. Friedman also advised us frequently at various stages of our work. The text and tables have greatly benefited from the careful editing of Isabel Davis and Elizabeth Todd.

This Bulletin is based on data obtained from the Study of Consumer Purchases, a Works Progress Administration project conducted by the United States Bureau of Home Economics and Bureau of Labor Statistics in cooperation with the National Resources Committee and the Central Statistical Board. We are under special obligation to the Bureau of Labor Statistics and the Bureau of Home Economics for making available to us the original tabulations of instalment-debt items from the Study of Consumer Purchases; and to the National Resources Committee for the use of unpublished mazerial on consumer incomes. In particular, we wish to express our appreciation to Faith Williams of the Bureau of Labor Statistics, to Day Monroe and Dorothy Brady of the Bureau of Home Economics, and to Hildegarde Kneeland of the National Resources Committee, for the suggestions and technical help they gave us during the preparation of our estimates.

\section{Aim ANd Scope}

Over the last twenty years the practice of financing consumer purchases by instalment or deferred payment credit has acquired increasing importance in the marketing of commodities. Although it is known that the use of instalment credit has spread through many income levels, no comprehensive statistical information on - its use by various consumer groups has been available.

This Bulletin presents such information for the year $1935-36$, describing the statistical pattern of instalment debt for the country as a whole, and thus delineating the broad outlines of the market for instalment credit. It contains estimates of the percentage of families in different income groups having a net change in instalment debt, $1935-36$, first for all commodities combined and then separately for six groups of commodities: automobiles, furniture, electric refrigerators, radios, 'other electric equipment', and miscellaneous commodities. ${ }^{1}$ We have also

${ }^{1} \mathrm{~A}$ further study in preparation by the National Bureau will contain additional data showing the percentage of families having a net change in instalment debt in various occupational and family-size groups. Estimates are also being made of the markets for charge account and cash loan credit, so that variations in the use of instalment credit, charge account credit, and cash loans may be compared. estimated which income groups were increasing and which were decreasing instalment obligations and the amount of average increase or average decrease. The year $1935-36$, to which our figures apply, was one of sharp business expansion, and these estimates therefore reflect the instalment-debt behavior of consumers during the expansion phase of one business cycle. In addition, we have undertaken to indicate how instalment buying habits vary in different types of communities and different regions. Our estimates of the pattern of instalment debt for all non-relief families in the United States during 1935-36 are based on a sample of 60,000 family expenditure schedules.

\section{Source and Limitations of Data}

The Study of Consumer Purchases, ${ }^{2}$ the source of our basic data, was a project of the Works Progress Administration. It

2The Study of Consumer Purchases is more completely described in Consumer Incomes in the United States (National Resources Committee, 1938), pp. 45-52, and in releases by the Bureau of Labor Statistics and the Bureau of Home Economics, presenting preliminary tabulations of the data. The tabulations of instalment debt in metropolises and large and middle-size cities, and in small cities in the East Central and New England regions, have been published in U. S. Bureau of Labor Statistics Bulletin 648, Vol. VIII; Changes in Assets 


\section{National Bureau of Economic Research}

consisted of an extensive field investigation conducted during $193^{6}$ in various communities throughout the United States. Data were collected in 51 cities, 140 villages, and 66 farm counties in 30 states, chosen to represent different geographic regions, degrees of urbanization, and types of farming areas. Information on family expenditures and changes in family debt during the preceding year ${ }^{3}$ was obtained from some 60,000 families, all nonrelief and mostly native white. ${ }^{4}$

One important qualification regarding the basic data should be borne in mind. On the original schedules the information obtained from each family referred only to net change in instalment debt during the year, not to the existence of instalment debt or to the total amount of such debt incurred. 'Net change' means simply the net increase or the net decrease in the balance due on instalment purchases. For example, a family owing $\$ 100$ on an automobile instalment debt at the beginning of the year, and retiring this debt completely during the year, would have reported a net decrease in debt of $\$ 100$. If the same family bought another car during the year, and had an unpaid balance of $\$_{300}$ on this purchase at the end of the year, a net increase in debt of $\$_{200}$ wrould have been reported. Figures on the total amount of instalment debt would have been easier to understand and somewhat more informative, but for many purposes net change in debt is equally significant.

As a result of this method of reporting indebtedness, families owing exactly as much at the end of the year as at the beginning were not included among families having a net change in debt, nor were families that had incurred instalment debt during the year and paid it off completely by the year-end; 5 but families were included whose indebtedness at the beginning of the year was entirely liquidated by the end.

To avoid continual use of the expression 'families having a net change in debt' we have adopted the term 'families indebted' as a synonym, using it to refer to families indebted during the year and not merely at the year-end, as it might seem to imply. Data showing the number of families having a net change in debt necessarily overestimate the number of families indebted at the end of the year. The number of families increasing debt would be

and Liabilities in Selected Cities. The instalment debt data for small cities in other regions and in villages and farms, which were tabulated by the Bureau of Home Economics, have not yet been published.

sThe majority of the schedules covered the year ending approximately June 30,1936 , but some applied to the calendar year 1935, and others covered the year immediately preceding the date of interview (in other words, a I 2-month period ending before or after June 30, 1936). In no case, however, did the schedule year end before December 1935, or after December 1936.

4In the South, and in New York City and large cities in the North Central region, expenditure schedules were obtained also from Negro non-relief families.

${ }^{5}$ This means that our estimates do not cover instalment debt of relatively short duration, contracted and liquidated between the terminal points of the schedule year. Short-term instalment obligations in existence either at the beginning or at the end of the year are included, however, since they do reflect a net change in debt. the minimum number that could be so described. The category of families decreasing debt includes both those still indebted at the end of the period and those who have completely liquidated instalment obligations. It is impossible from available data to estimate the importance of the latter group and thus indicate the degree to which the number of families indebted at the end of the year has been overestimated.

We shall also employ the terms 'frequency of debt' and 'extent of use of instalment credit', using them as synonyms for the percentage of families having a net change in debt or the percentage of families indebted during the year. As we use the phrase, 'extent of use of instalment credit', it pertains to the percentage of families making payments on instalment purchases, whether bought in the given year or earlier-in other words, to the percentage of families having a net change in debt. ${ }^{6}$ Thus, it does not mean the percentage of families making instalment purchases during the year. The latter interpretation of the term is best approximated in our data by the percentage of families increasing debt. This percentage, however, would only roughly indicate that of families making purchases during the year; some families decreasing debt may also have made new instalment purchases, their effect being counterbalanced by repayments on old purchases.

Another limitation of the data arises from the fact that the original expenditure schedules were obtained only from nonrelief native white (and Negro) families. Single individuals were excluded, ${ }^{7}$ as were relief and foreign-born families, so that there are no data to indicate whether or not the debt pattern of these groups resembles that of the families included. Finally, in each type of community data are lacking for certain income classesthe very high income groups in some, the very low in others.

The Appendix to this Bulletin discusses these limitations in the coverage of the data and assesses their bearing on our final results. It also outlines the methods by which national estimates were built up from the sample covering 60,000 families.

\section{Summary of Findings}

a) Our estimates show that almost one-quarter of all non-relief families in the United States had a net change in instalment debt during $1935-36$, and that the use of instalment credit, as indicated by these data, varied with income level. The proportion of families in each income class indebted for instalment purchases rose steadily from approximately to per cent in the group receiving less than $\$ 250$ a year to 32 per cent in the $\$ 1750-2000$ band, and then declined consistently.

b) A sharp increase in instalment buying occurred during

6Families having a net change in debt and families making instalment payments during the year are not actually identical, since families owing as much at the end as at the beginning of the year and families incurring and paying off obligations within the year would not be included among the former. It is not believed, however, that the difference is very large.

'Except in two cities, Chicago and Portland (Oregon), but these data have not been incorporated in our estimates. 


\section{The Statistical Pattern of Instalment Debt}

the expansion period $1935-36$. More than 70 per cent of the families having a net cliange in instalment debt increased their instalment obligations. At all income levels more families were increasing than were decreasing their obligations, but the increases were relatively more frequent among lower than among higher income families.

c) Both the average debt-increase of families increasing debt and the average debt-decrease of families decreasing debt (for all types of commodities combined) rose steadily as income advanced, indicating that the use of instalment credit is usually. associated with purchases that in price and quantity are related to size of family income. But both average increase and average decrease in debt formed a diminishing proportion of total family income as income increased from the lowest to the highest levels. Average increase declined from 6I per cent of income in the lowest income band (under $\$ 250$ ) to 4 per cent in the highest band (\$5000 and over).

d) The net increase (sum of all increases minus sum of all decreases) ${ }^{8}$ in instalment debt attributable to non-relief families totaled over $\$ 407,000,000$. Families having incomes between $\$ 1000$ and $\$ 2000$ were responsible for almost half of this net increase in debt, though only 40 per cent of non-relief families are in this income band.

e) Income classes below $\$ 1500$ included a smaller share of the gross increase (sum of all increases) in debt than of the number of families increasing debt, and a smaller share of the gross decrease (sum of all decreases) than of the number of families decreasing debt, indicating a smaller average size of debt. Families above the $\$ 1500$ level, on the other hand, exhibited the reverse tendency, holding a more than proportionate share of the gross increase and decrease in instalment debt. A disproportion, though not so marked, existed also between the distribution of families indebted for instalment purchases and the distribution of the net increase in debt.

f) Almost one-third of the instalment-debt changes of families living in metropolises and large and middle-size cities applied to purchases of furniture, one-fifth to automobiles, onethird to electric refrigerators and 'other electric equipment', and one-twelfth to radios. ${ }^{9}$ Less than one-tenth of the debt changes related to the 'miscellaneous commodity' category, which includes non-durable or 'soft' consumers' goods; this suggests that the instalment credit device had not made extensive inroads into the soft goods market by 1935-36. Soft goods, however, are often sold on very short contracts with payments scheduled weekly, so that purchases made and paid off during the year would have escaped reporting under the method employed in obtaining the original sample data. Therefore the 'miscellaneous ${ }^{8}$ Gross increase means the sum of increases in debt of families having a net increase. Gross decrease is the sum of decreases in debt of families having a net decrease. Net increase equals gross increase minus gross decrease.

9It is probable that if smaller types of communities had been included these proportions would differ to some extent, with automobiles forming a slightly larger, and furniture and electric refrigerators a smaller, proportion of the total debt changes. commodity' category underestimates the number of soft goods instalment transactions during this period.

g) Many families, of course, carried instalment debt on more than one commodity. Our data show that as income rose to the level of $\$ 3000$, there was an increasing tendency for families to owe for more than one commodity, but above this level the tendency was reversed.

h) Automobile purchases, the greatest source of dollar volume of instalment debt, were responsible for over 50 per cent of the gross increase in instalment debt during the year 1935-36, and for almost 60 per cent of the net increase. Furniture purchases represented the second largest source of gross increase, and the largest source of gross decrease in debt, so that in this year they formed a relatively insignificant element in the net increase in instalment debt.

i) The use to which instalment credit was put varied in different income groups. In the lower income levels (under $\$ 1000)$ furniture was the commodity most frequently financed on instalment terms, with radios, 'other electric equipment', and miscellaneous articles next in importance. Families with incomes between $\$ 1000$ and $\$ 2000$ were making instalment payments on furniture, automobiles, electric refrigerators, and 'other electric equipment' more frequently than on the other types of commodities; and above the $\$ 2000$ income level instalment debt was most often related to automobiles.

j) For every type of commodity financed on instalment terms, more families in each income group were increasing than were decreasing debts, and increases were in every case relatively more numerous among lower income families (under \$2000) than among higher income families. The ratio of families increasing to those decreasing instalment obligations was smaller, however, for furniture and electric refrigerators than for other commodities. This may have resulted from the fact that furniture and electric refrigerators are usually sold on longer terms.

k) For all commodities except furniture the average debtincrease was generally higher than the average debt-decrease. That average debt-increase is higher is due in part to differences in the average duration and age of instalment contracts as between families increasing and those decreasing debt; it suggests also that possibly unit instalment purchases were larger, on the whole, during 1935-36 than in the preceding year, and that unit furniture purchases, on the other hand, were smaller during 1935-36 than in 1934-35. For each commodity group both average debt-increase and average debt-decrease were directly related to income; that is, they rose as income advanced. This supports the contention that the use of instalment credit is usually associated with purchases of commodities at prices or in quantities compatible with size of family income.

1) The proportion of gross increase and gross decrease in debt originating with families having incomes under $\$ 1000$ and over $\$ 3000$ varied widely for the different commodities. For all commodities except automobiles, however, approximately half of the gross increase and gross decrease in debt came from families having annual incomes berween $\$ 1000$ and $\$ 2000$. Most of 


\section{National Bureau of Economic Research}

the net increase in instalment outstandings (for all commodities cxcept automobiles) originated $w$ ith families whose annual incomes were under $\$ 2000$.

m) The use of instalmen: credit is definitely an urban phenomenon; data covering the North Central region indicate that approximately 70 per cent of families indebted for instalment purchases were urban dwellers. In all income classes the frequency of instalment debt was highest in large, small, and medium-size cities in this region, in the order mentioned; villages ranked fourth and metropolitan centers fifth. Among farm families the frequency of debt was very much lower than in any other type of community, probably because of the irregular flow of farm income. Urban families were most often indebted for furniture and next most frequently for automobiles, while among village and farm families automobiles were foremost. Over 50 per cent of the families indebted for all commodities, except automobiles ( 43 per cent) and the miscellaneous group ( 32 per cent), were residents of large or small cities, although only onethird of the population lived in these communities. In contrast, metropolitan and farm families in general constituted a smaller proportion of the families indebted for instalment purchases than of the population.

n) The use of instalment credit varied also among regions. One-third of all families in the Pacific region were indebted for instalment purchases, one-fifth of the families in the North Central region, and one-fourth in the other regions. The Pacific region, however, had the highest frequency of debt only in the income levels below $\$ 2000$. Above this level families in the

\section{TABLE I}

Percentage of Non-Relief Families having a Net Change in Instalment Debt, and their Percentage Distribution, 1935-1936, by Income Level

\begin{tabular}{|c|c|c|c|}
\hline \multirow[b]{2}{*}{ ANNCAL INCOME } & \multirow[b]{2}{*}{$\begin{array}{l}\text { PERCENTAGE } \\
\text { OF FAMILIES }\end{array}$} & \multicolumn{2}{|c|}{ PERCENTAGE DISTRIBUTION } \\
\hline & & $\begin{array}{l}\text { Families having } \\
\text { a net change in } \\
\text { instalment debt }\end{array}$ & $\begin{array}{l}\text { All non- } \\
\text { relief } \\
\text { families }\end{array}$ \\
\hline Under $\$ 250$ & 10.4 & 1.2 & 2.8 \\
\hline $250-500$ & 12.3 & 4.1 & 7.8 \\
\hline $500-750$ & 16.8 & 8.1 & 11.3 \\
\hline $750-1000$ & $21 \cdot 3$ & 12.1 & ${ }^{1} 3 \cdot 4$ \\
\hline $1000-1250$ & 24.9 & 13.9 & 13.2 \\
\hline $1250-1500$ & 27.6 & 12.6 & 10.8 \\
\hline $1500-1750$ & 29.0 & I 1.1 & $9 . \mathrm{r}$ \\
\hline $1750-2000$ & 31.9 & 9.9 & $7 \cdot 3$ \\
\hline $2000-2500$ & 30.2 & 12.2 & 9.5 \\
\hline $2500-3000$ & 29.3 & 6.5 & 5.2 \\
\hline $3000-+000$ & 23.8 & 4.8 & 4.8 \\
\hline $4000-5000$ & 21.5 & 1.5 & I. 6 \\
\hline 5000 and over & 15.0 & 2.0 & 3.2 \\
\hline Total & 23.6 & 100.0 & 100.0 \\
\hline \multicolumn{2}{|c|}{$\begin{array}{l}\text { Estimated number of } \\
\text { families (in millions) }\end{array}$} & 5.8 & 24.9 \\
\hline
\end{tabular}

1.Adapted from Consumer Incomes in the United States, Table 8, p. 25.
South used instalment credit to a greater extent than Pacific families. Debt for furniture, refrigerators, and radios was most prevalent in the South, but the greatest debt frequency for automobiles and miscellaneous goods occurred in the Mountain-andPlain region, and for 'other electric equipment' in the Pacific region.

These regional differences in instalment buying behavior only partly reflect cultural and social variations. Since instalment buying is primarily an urban phenomenon, the type of city that predominates in a given region, and the distribution of urban family incomes in the region, must also be considered important factors causing regional variation.

\section{Use of Instalment Credit by Different Income Groups}

Table I, based on data from all types of communities, shows that almost one-quarter of the non-relief families in the United States were indebted for instalment purchases during 1935-36, and indicates that instalment credit was used by all but the very wealthy. The extent of its use, however, varied considerably at different income levels, as is illustrated in Chart I.

Less than 13 per cent of families in the very low annual income levels (under $\$ 500$ ) were indebted for instalment purchases, and roughly 20 per cent of those between $\$ 500$ and $\$ 1000 .{ }^{10}$ The percentages continue to rise steadily to a peak of 32 per cent at the \$1750-2000 income level, and then decline consistently; only is per cent of families with incomes of $\$ 5000$ or over had a change in instalment debt. At all income levels between $\$ 1000$ and $\$ 4000$, however, approximately one out of every four families was indebted for instalment purchases.

Table I indicates further that over 90 per cent of families indebted for instalment purchases had incomes of less than $\$ 3000$ a year. A comparison of the distribution of all non-relief families and of families indebted for instalment purchases (Chart II) shows that in some income groups there was a considerably larger proportion of instalment debtors than of the total population. More than one-third of non-relief families in the country have incomes under $\$ 1000$ a year, but barely one-quarter of the families carrying instalment debt were in these income classes. On the other hand, each income band between $\$ 1000$ and $\$ 3000$ included a larger proportion of families indebted for instalment purchases than of all non-relief families. Approximately 40 per cent of non-relief families had incomes between $\$ 1000$ and $\$ 2000$, but almost half of the families indebted for instalment purchases were in this income band; and the is per cent of families who had annual incomes of $\$ 2000$ to $\$ 3000$ comprised over I 8 per cent of the instalment purchasers. Between $\$ 3000$ and $\$ 5000$ the number of families having debt was about proportionate to the number of families having incomes within these limits, but above $\$ 5000$ a less than proportionate number of families had instalment debt.

Instalment buying rose markedly during 1935-36. Of an 10. At each level incomes of exactly the higher amount are included in the succeeding level; that is, an income of exactly $\$ 1000$ is included in the $\$ 1000-1250$ income group. This practice is followed in all tables. 


\section{The Statistical Pattern of Instalment Debt}

estimated total of $5 . S$ million non-relief families having a change in instalment debt 4.1 million, or about 70 per cent, had increased their obligations during the year; only I.7 million decreased their debts (Table 2). Within the different income levels, of course, the proportion of families increasing debts varied (Chart III); it declined more or less steadily from 84 per cent in the lowest income band (under $\$ 250$ ), to 62 per cent in the second highest income level ( $\$_{4000-5000}$ ), and rose to 69 per cent for families with incomes of $\$ 5000$ and over.

Thus at all income levels far more families were increasing than were decreasing their instalment indebtedness during this period of business advance, but the tendency was strongest among the lower income families. Chart IV reflects the fact that this tendency was particularly marked for families with incomes below $\$ 750$, with the consequence that the band below $\$ 750$ included proportionately more families that were increasing than families that were decreasing debts. It will be shown in Section 5

- that there were noteworthy variations in the distribution patterns of families increasing and decreasing debts for some types of commodities.

Both average increase and average decrease in debt rose steadily as income mounted from the lowest to the highest levels (Table 3), reflecting the fact that instalment credit purchases, like cash purchases, tend to be related in price and quantity to the size of family income; in other words, that the use of instalment credit does not ordinarily change the fact that lower income families must purchase smaller quantities of goods, at lower prices, than higher income families.

The lower income groups, however, devoted a considerably larger percentage of income to instalment purchases than higher income families. The proportion of family income required for the average increase in instalment obligations declined con-

\section{TABLE 2}

Percentage of Non-Relief Families Increasing or Decreasing Instalment Debt, and their Percentage Distribution, 1935-1936, by Income Level

\begin{tabular}{|c|c|c|c|c|}
\hline \multirow[b]{2}{*}{ ANNUAL INCOME } & \multicolumn{2}{|c|}{$\begin{array}{l}\text { PERCENTAGE } \\
\text { OF FAMILIES }\end{array}$} & \multicolumn{2}{|c|}{$\begin{array}{l}\text { \% DISTRIBLTION } \\
\text { OF FAMIILIES }\end{array}$} \\
\hline & $\begin{array}{l}\text { Increas- } \\
\text { ing } \\
\text { debt }\end{array}$ & $\begin{array}{l}\text { Decreas- } \\
\text { ing } \\
\text { debt }\end{array}$ & $\begin{array}{l}\text { Increas- } \\
\text { ing } \\
\text { debt }\end{array}$ & $\begin{array}{l}\text { Decreas- } \\
\text { ing } \\
\text { debt }\end{array}$ \\
\hline Under $\$ 250$ & 8.7 & 1.7 & I. 5 & .7 \\
\hline $250-500$ & $9 \cdot 3$ & 3.0 & $4 \cdot 4$ & 3.3 \\
\hline $500-750$ & 12.4 & $4 \cdot 4$ & 8.5 & 7.1 \\
\hline $750-1000$ & 14.8 & 6.5 & I 2.0 & 12.4 \\
\hline $1000-1250$ & 17.5 & $7 \cdot 4$ & 13.9 & 13.8 \\
\hline $1250-1500$ & 19.5 & 8.1 & 12.7 & 12.4 \\
\hline $1500-1750$ & 20.0 & 9.0 & 10.9 & 11.6 \\
\hline $1750-2000$ & 22.5 & $9 \cdot 4$ & 10.0 & 9.8 \\
\hline $2000-2500$ & 21.0 & 9.2 & .12 .0 & I 2.4 \\
\hline $2500-3000$ & I9.9 & 9.4 & 6.3 & 7.0 \\
\hline $3000-4000$ & 15.6 & 8.2 & $4 \cdot 5$ & 5.5 \\
\hline $4000-5000$ & 13.4 & 8.1 & I. 3 & 1.9 \\
\hline 5000 and over & 10.4 & 4.6 & 2.0 & 2.1 \\
\hline Total & 16.6 & 7.0 & 100.0 & 100.0 \\
\hline $\begin{array}{l}\text { Estimated number of } \\
\text { families (in millions) }\end{array}$ & & & 4.1 & 1.7 \\
\hline
\end{tabular}

Chart I

PERCENTAGE OF NON-RELIEF FAMILIES HAVING A NET CHANGE IN INSTALMENT DEBT, 1935-1936, BY INCOME LEVEL

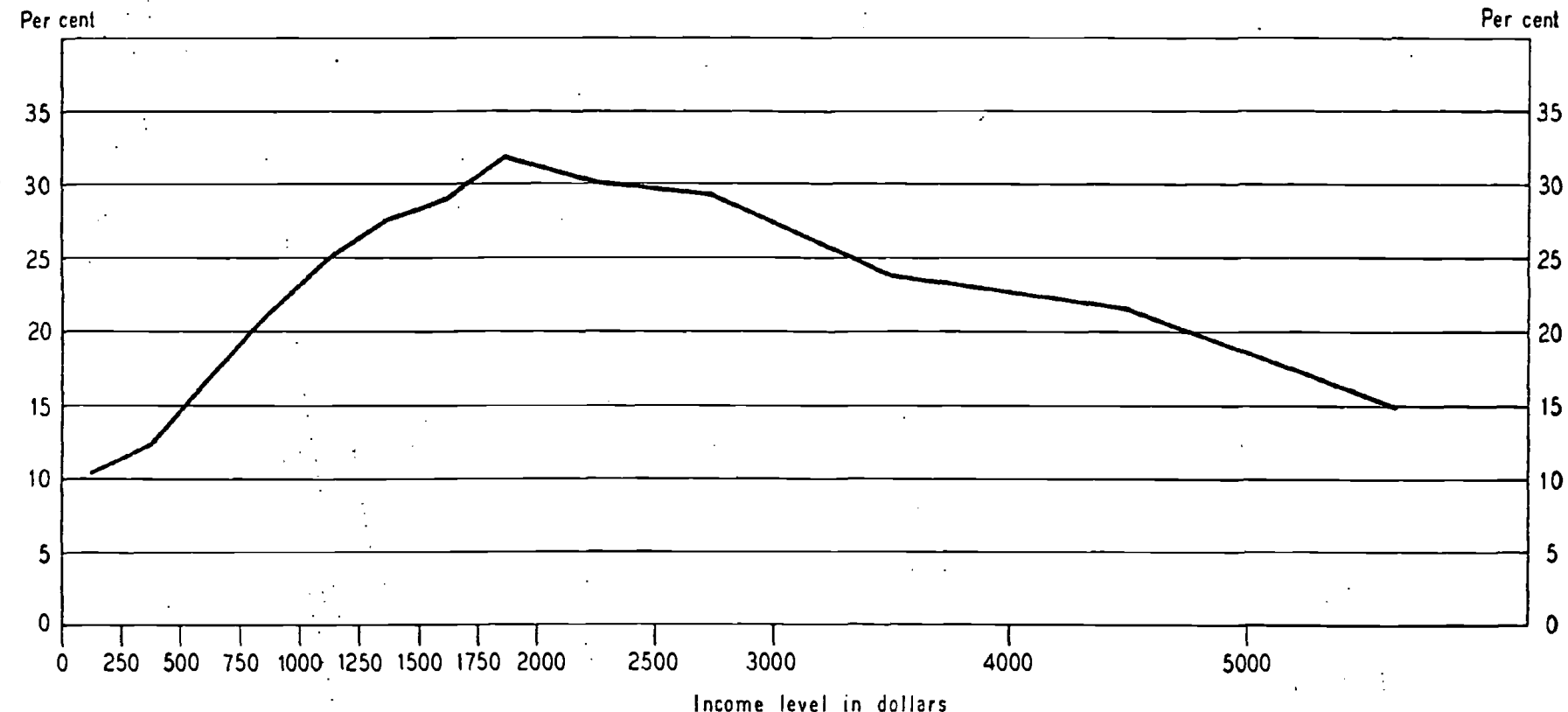




\section{National Bureau of Economic Research}

sisrently from 6 I per cent in the income band under $\$ 250$, and 19 per cent in the $\$ 250-500$ level, to 4 per cent in the highest income group. Similarly, the proportion of family income represented by the average decrease in instalment debt declined from 30 per cent in the lowest income level and ro per cent in the \$250-500 class to under 5 per cent in the $\$ 5000$ and over group.

Average increase in instalment debt was larger than average decrease in every income class except the $\$ 5000$ and over group. As income rose, however, the ratio of average increase to average decrease declined from a peak of 2 in the lowest level to 1.3 in the $\$ 1250-2000$ level, and 1.1 in the three levels between $\$ 2500$ and $\$ 5000$; above this level of income the ratio of average increase to average decrease was 0.8 . This relationship results in part from the fact that the commodities most frequently purchased on instalment terms differ in different income levels. As will be seen in Section 5, furniture was the commodity most frequently purchased on instalment terms by families with incomes below $\$ 2000$, and automobiles were the most frequently purchased commodity by families with incomes above this level. For families with incomes between $\$ 1000$ and $\$ 1750$ electric refrigerators and 'other electric equipment' were the next most frequent instalment purchase after furniture. The longer the typical duration of contract on the commodities purchased, the greater the bias toward a larger average increase than average decrease in debt, and the typical contracts for furniture and electric refrigerators are longer than those for automobiles. The general tendency for the ratio of average increase to average decrease to decline as income rises is apparent also when the data for average. increase and decrease are analyzed by commodities (Tंable $\mathrm{II}$ ).

TABLE 3

Average Increase and Decrease in Instalment Debt of NonRelief Families Increasing or Decreasing Instalment

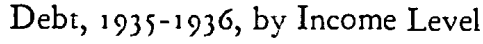

\begin{tabular}{|c|c|c|c|c|}
\hline $\begin{array}{l}\text { A.NiCAL } \\
\text { INCOSIE }\end{array}$ & $\begin{array}{l}\text { AlERAGE } \\
\text { LNCREASE }\end{array}$ & $\begin{array}{c}\text { RATIO OF } \\
\text { AVERAGE 1NCREASE } \\
\text { IO AVERAGE INCOASE1 }\end{array}$ & $\begin{array}{l}\text { AVERAGE } \\
\text { DECREASF. }\end{array}$ & $\begin{array}{l}\text { RATHO OF } \\
\text { AVERAGE DECREASE } \\
\text { TO AVERAGE INCOIIE] }\end{array}$ \\
\hline Under $\$ 250$ & $\$ 7 I$ & 60.7 & $\$ 35$ & 29.9 \\
\hline $250-500$ & 72 & 18.6 & 39 & 10.1 \\
\hline $500-750$ & 87 & 13.9 & 54 & 8.6 \\
\hline $750-1000$ & 100 & 11.4 & 60 & 6.9 \\
\hline $1000-1250$ & 124 & II.I & 79 & 7.1 \\
\hline $1250-1500$ & 132 & $9 \cdot 7$ & 102 & 7.5 \\
\hline $1500-1750$ & 154 & 9.6 & II 8 & $7 \cdot 3$ \\
\hline $1750-2000$ & I $8 \mathrm{I}$ & $9 \cdot 9$ & $I_{4} \mathrm{I}$ & $7 \cdot 7$ \\
\hline $2000-2500$ & 195 & 8.8 & 157 & 7.1 \\
\hline $2500-3000$ & 216 & 8.0 & 190 & 7.0 \\
\hline $3000-4000$ & 234 & 6.9 & 215 & 6.3 \\
\hline $4000-5000$ & 284 & 6.5 & 252 & $5 \cdot 7$ \\
\hline 5000 and over & 336 & 3.9 & 4 II & 4.8 \\
\hline Total & 151 & $9 \cdot 3$ & 122 & $7 \cdot 5$ \\
\hline
\end{tabular}

The average income in each class was derived from Consumer Incomes in the United States, Table 3, p. I 8, by dividing the aggregate income received by the total number of families in each income class. The average income for the $\$ 5000$ and over group represents the average for families having incomes between $\$ 5000$ and $\$ 20,000$.

Chart II

\section{PERCENTAGE DISTRIBUTION. OF NON-RELIEF FAMILIES HAVING A NET CHANGE IN INSTALMENT DEBT, OF ALL NON-RELIEF FAMILIES, AND OF NET INCREASE IN INSTALMENT DEBT, 1935-1936, BY INCOME LEVEL}

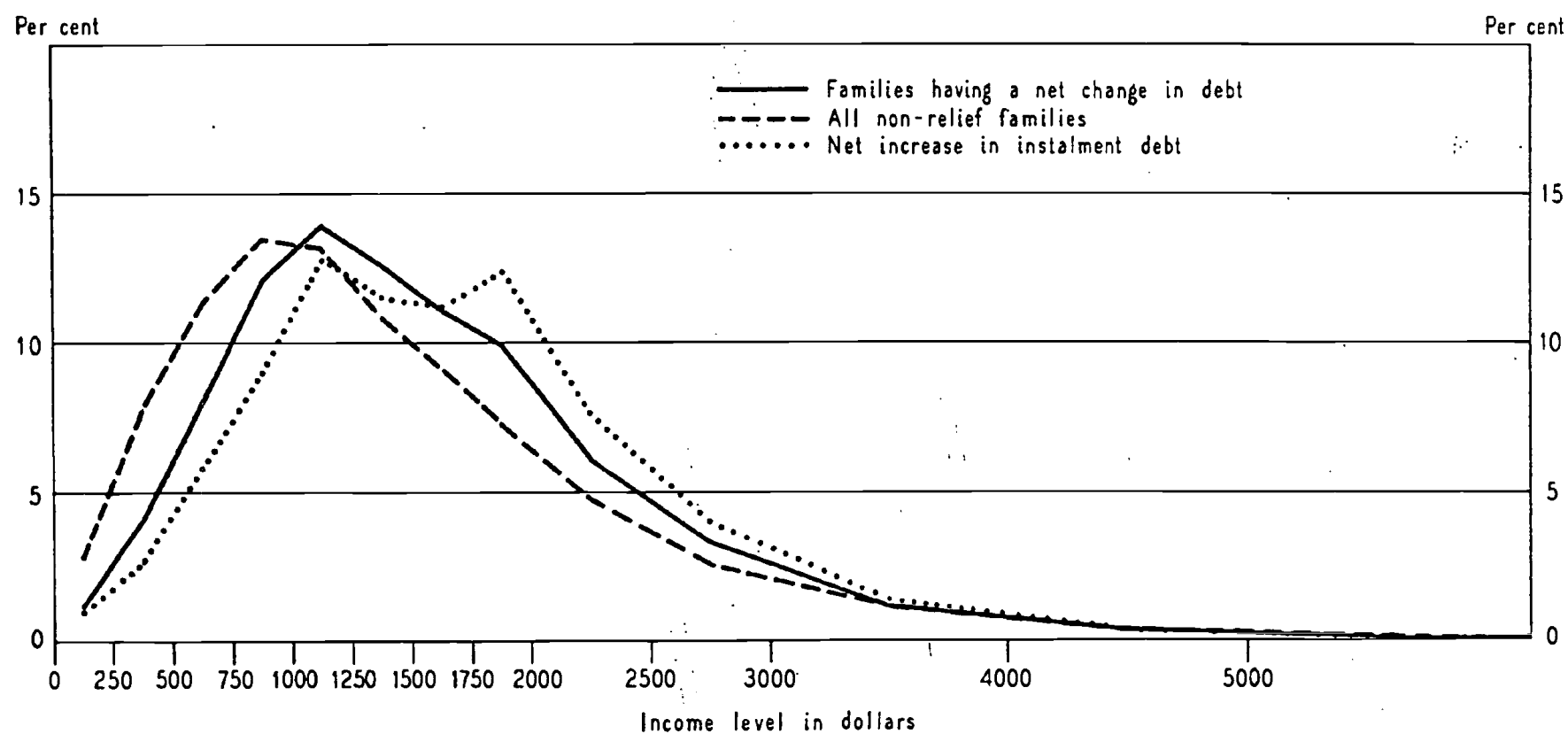




\section{The Statistical Pattern of Instalment Debt}

Here, however, the tendency is neither so consistent nor so pronounced as when all commodities are combined. It seems reasonable to suggest, therefore, that the declining ratio for all commodities reflects also a tendency for lower income families to increase the amount of their instalment debt proportionately more than did higher income families during this expansion period.

The total amount and distribution of the gross increase (sum of all increases), the gross decrease (sum of all decreases), and the net increase (gross increase minus gross decrease) are shown in Table 4. It must be remembered that these estimates relate only to non-relief families, and that therefore the total of over $\$_{407,000,000}$ of net increase in debt does not represent the entire increase in outstandings during this period. ${ }^{11}$ Over two-fifths of the gross increase and gross decrease, and almost half of the net increase, in outstandings during this period were attributable to families having annual incomes from $\$ 1000$ to $\$ 2000$. Each income class below $\$ 2000$ had a larger proportion of the gross increase than of the gross decrease in debt (except the \$1 500-I 750 level, where the two were the same), and above $\$ 2000$ each in-

"A rough estimate of the amount of instalment debt held by single individuals and relief families-computed by assuming that the debt pattern is the same for these groups as for non-relief families-indicates a total increase in outstandings of $\$ 580,700,000$. This figure closely approximates an independent estimate of instalment outstandings to be presented by the National Bureau in a forthcoming Bulletin on quantitative measures in the field of consumer instalment financing. come class had a smaller proportion of the gross increase than of the gross decrease.

Comparison of the tables showing the distribution of fam-

$$
\text { TABLE } 4
$$

Percentage Distribution of the Gross Increase, Gross Decrease, and Net Increase in Instalment Debt of Non-Relief Families, I935-1936, by Income Level

\begin{tabular}{lccc}
\hline ANNUAL INCOME & $\begin{array}{c}\text { GROSS } \\
\text { INCREASE }\end{array}$ & $\begin{array}{c}\text { GROSS } \\
\text { DECREASE }\end{array}$ & $\begin{array}{c}\text { NET } \\
\text { INCREASE }\end{array}$ \\
Under $\$ 250$ & .7 & .2 & 1.0 \\
$250-500$ & 2.1 & 1.1 & 2.7 \\
$500-750$ & 4.9 & 3.1 & 5.8 \\
$750-1000$ & 8.0 & 6.1 & 9.0 \\
$1000-1250$ & 11.5 & 9.0 & 12.7 \\
$1250-1500$ & 11.1 & 10.4 & 11.5 \\
$1500-1750$ & 11.2 & 11.2 & 11.2 \\
$1750-2000$ & 12.2 & 11.4 & 12.3 \\
$2000-2500$ & 15.6 & 16.0 & 15.5 \\
$2500-3000$ & 9.0 & 10.9 & 8.0 \\
$3000-4000$ & 6.9 & 9.8 & 5.5 \\
$4000-5000$ & 2.5 & 3.8 & 1.7 \\
5000 and over & 4.5 & 7.0 & 3.1 \\
& & & \\
Total & 100.0 & 100.0 & 100.0 \\
& & & \\
Estimated change (in millions) & $\$ 620.9$ & $\$ 213.3$ & $\$ 407.6$ \\
\hline
\end{tabular}

Chart III

\section{PERCENTAGE OF NON-RELIEF FAMILIES INCREASING OR DECREASING INSTALMENT DEBT, 1935-1936, BY INCOME LEVEL}

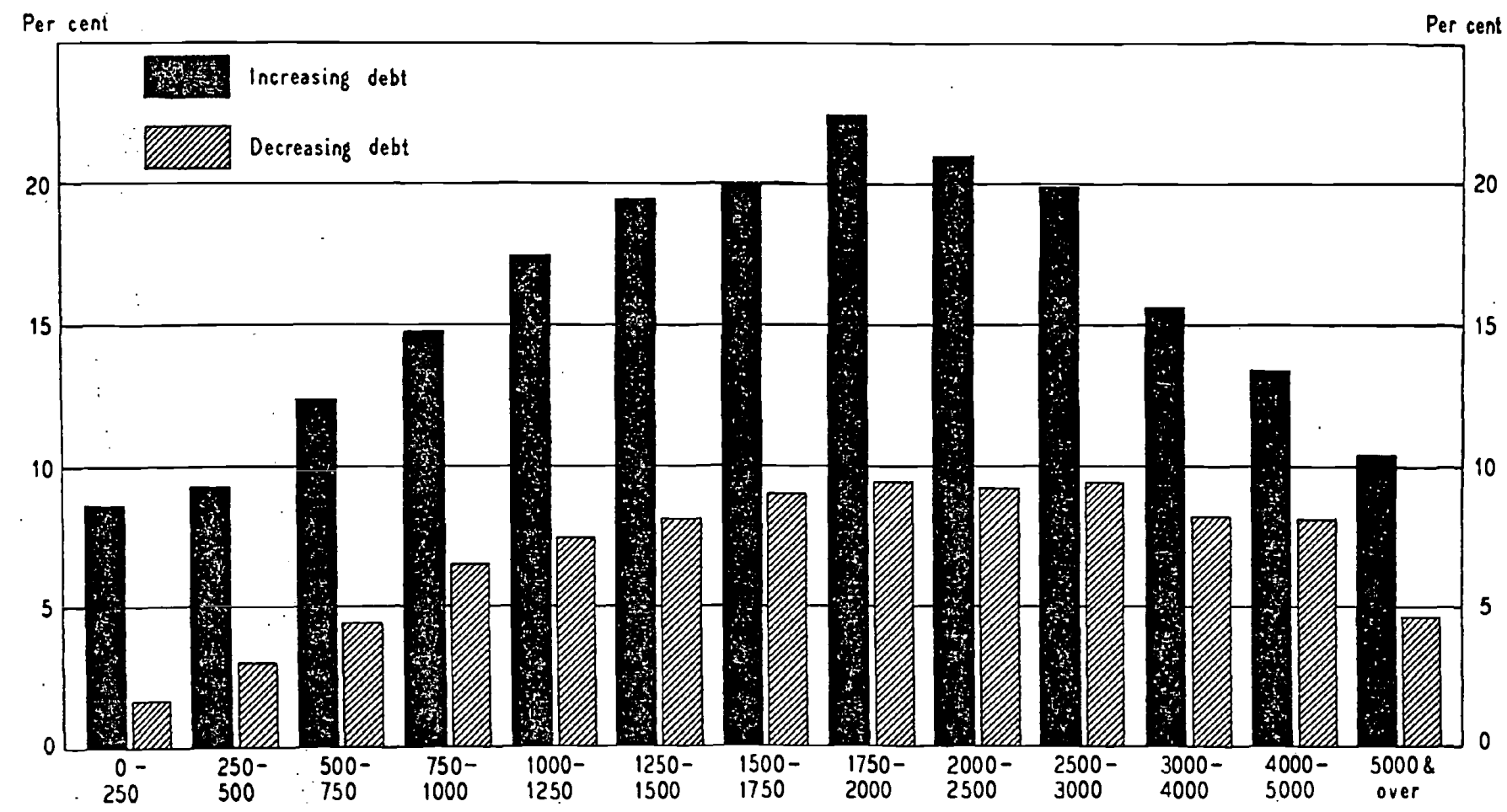

Income level in dollars 


\section{National Bureau of Economic Research}

ilies increasing and decreasing instalment obligations with the clistribution of the gross increase and decrease indicates that the loner income families held a less than proportionate share of the debt: over 26 per cent of families having an increase in debt had incomes of less than $\$ 1000$, but these families accounted for less than 16 per cent of the gross increase in instalment debt; similarly, this lower income group included about 24 per cent of the famlies decreasing debts but less than in per cent of the gross decrease. The income classes above $S_{1} 500$, on the other hand, inclucled a larger share of the gross increase and decrease than of the families increasing or decreasing. A similar, though not so marked, disproportion exists between the distribution of families having a net change and the distribution of the net increase in instalment debt. Of all families having a net change in instalment debt 52 per cent had incomes of less than $\$ 1500$, and were responsible for about 43 per cent of the net increase in instalment outstandings.

\section{The Patteri of Debt Changes by Types of Commod- ITIES}

Instalment credit, first used mainly for the purchase of furniture, began to develop rapidly in the early 1920's as a means of facilitating the purchase of automobiles. It has since spread to many less durable commodities, being widely promoted today even in the purchase of 'soft' or perishable goods. Our estimates indicate that about 80 per cent of the number of $1935-36$ instalment-debt changes relate to commodities other than automobiles.

Furniture was the source of about one-third of the instalment-debt changes in $1935-36$. Automobiles were second in importance, being the source of instalment debt in 20 per cent of the debt clianges; approximately another one-third ot the instalment-debt changes were divided almost equally bermen electric refrigerators and 'other electric equipment' (Table ; and Chart $v)$. These estimates are based on data obtained from families living in metropolises and large and middle-size cities. In view of the data to be presented in Section 7, which show distinct variations in the distributions of instalment-debt changes by kind of commodity in difierent types of communities in one region, it seems probable that had data from smaller communities been included in this table the proportions would difier to some extent. Automobiles would form a larger, and furniture and elecitic refrigerators a smaller, proportion of the total deb: changes.

Less than so per cent of the debt changes wiere in the miscellaneous commodity category, which includes 'soft' goods purchased on instalment terms as well as other durable goods not included in the individual commodity groups. This suggests that instalment credit had not yet made extensive inroads into the 'soft' goods market by 1935-36. Instalment purchases of soft goods, however, are made on relatively short-term contracts with payments usually scheduled weekly, and since families who incurred and paid off obligations within the year are nor included in these instalment-debt data, the miscellaneous category probably underestimates the number of instalment transactions of 'sof $\mathrm{t}$ ' goods in liquidation during this period.

Furniture and electric refrigerators had less than proportionate shares of the total number of debt-increases: almost 60 per cent of the reductions in instalment obligations related to these two items, compared with less than 42 per cent of the increases

Chart IV

\section{PERCENTAGE DISTRIBUTION OF NON-RELIEF FAMILIES INCREASING OR DECREASING INSTALMENT DEBT, 1935-1936, BY INCOME LEVEL}

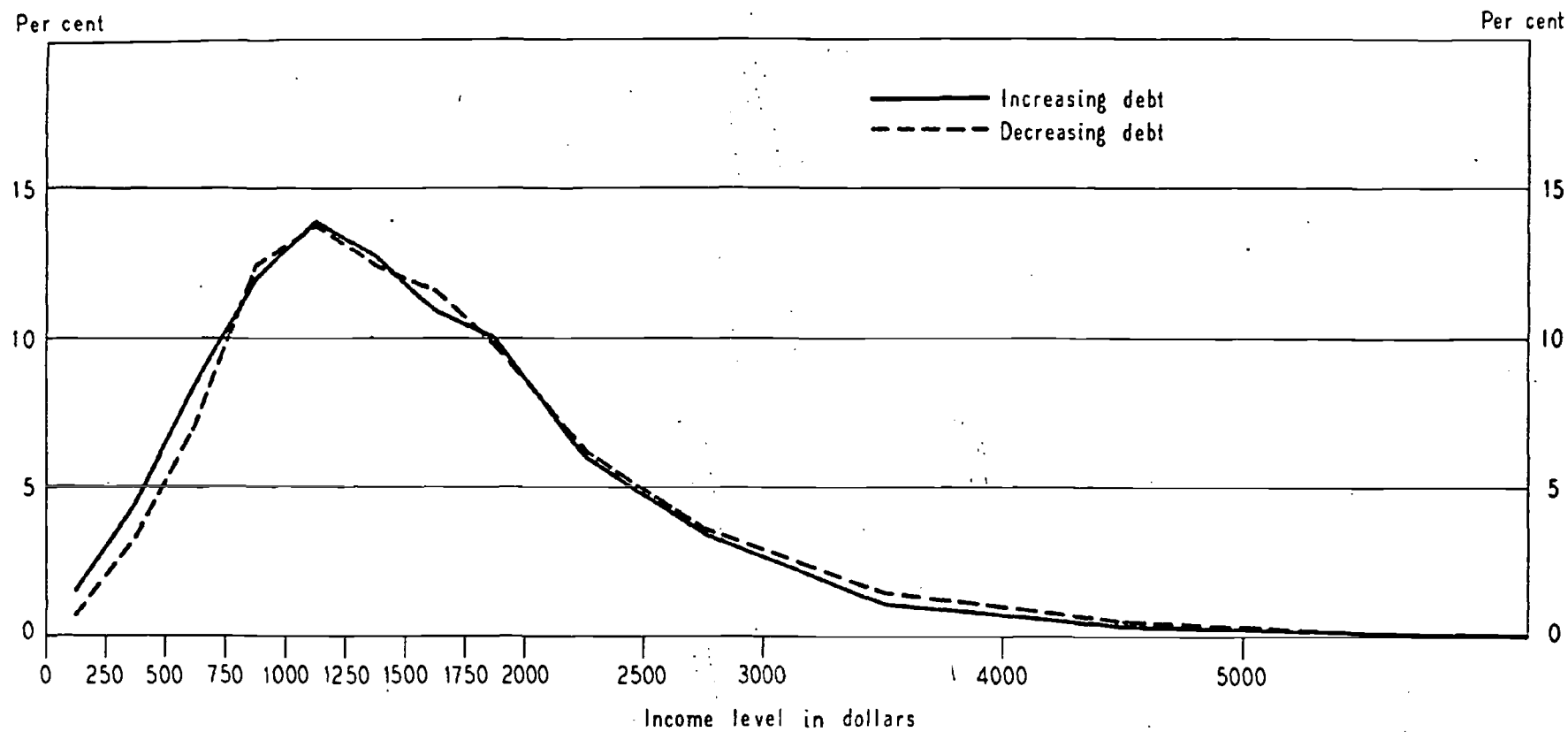




\section{The Statistical Pattern of Instalment Debt}

in debts. The other commodities had substantially smaller shares in the distribution of all debt-decreases than of all debt-increases.

The number of instalment-debt changes involving a given commodity is not an index of that commodity's significance as a source of the dollar volume of instalment debt. In volume automobiles were by far the most important single source of instalment debt (Table 6 and Chart VI), a fact accounted for by their higher unit prices compared with other commodities. About one-fifth of the number of instalment-debt changes during 193536 were for automobiles, but in dollar amount of instalment credit they were responsible for over 50 per cent of the gross increase and almost 60 per cent of the net increase.

Furniture represented a large percentage of the number of instalment-debt changes, but it was only a minor element of the net increase in dollar outstandings. This reflects the fact that although many more families were increasing than were decreasing furniture obligations, ${ }^{12}$ in all income bands but two ${ }^{13}$ the average debt-increase (of families increasing debts) was less than the average debt-decrease (of families decreasing debts), ${ }^{14}$ and

12See Table 9, which indicates what proportion of the families indebted for each commodity were increasing their debt.

$13 \$ 500-1000$ and $\$ 1000-1500$; See Table 11 .

14 ne cause of this relationship may be the fact that couples married less than a year, who might be expected to make large purchases of furniture, were excluded from the expenditure study. Such families, however, amounted to approximately 2 per cent of the families in the random sample.

\section{Chart V}

\section{PERCENTAGE DISTRIBUTION OF ALL} INSTALMENT DEBT CHANGES,

\section{5-1936, BY COMMODITIES}

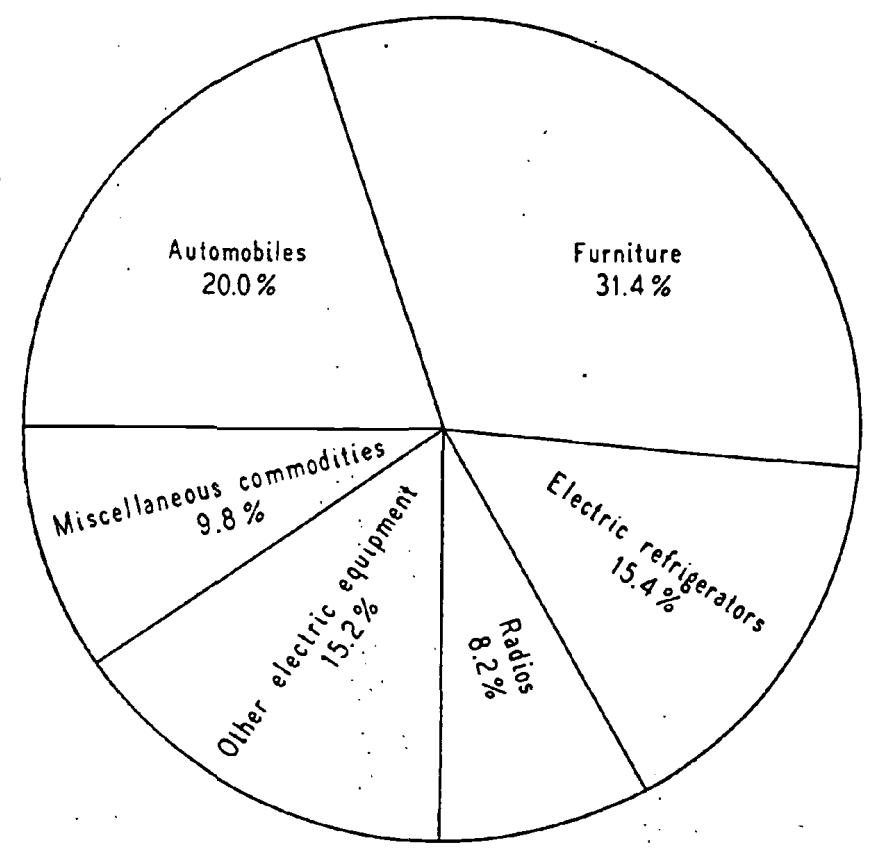

it would indicate that unit instalment purchases of furniture had been larger in the preceding year (1934-35) than in the one under consideration.

Table 7 indicates, by income groups, the frequency of instalment debt for different types of commodities. Furniture was more commonly financed by instalment payments than any other commodity, with automobiles second. Chart VII shows, however, that the instalment financing of furniture was relatively most frequent only in income bands below $\$ 2000$; above this level the purchase of automobiles took first place. In income groups below $\$ 1000$ families indebred for automobiles were fewer than those indebted for any other commodity; ${ }^{15}$ but in the income group above $\$ 5000$ they were four times as numerous as those indebted for furniture, comprising 9 per cent of all families having such incomes, compared with 2 per cent indebted for purchases of furniture.

Below the $\$ 1000$ level radios, 'other electric equipment', and miscellaneous commodities ranked closely together in frequency of financing on instalment terms. Between $\$ 1000$ and $\$ 1750$ refrigerators and 'other electric equipment' were, except for furniture and the increasing number of automobiles, the most frequent items financed. Above $\$ 1750$ automobiles assumed the second rank, and above $\$ 2000$ they were the commodity most frequently financed, refrigerators and 'other electric equipment' taking third and fourth places respectively.

In the figures on instalment debt by commodities each family appears once for each commodity purchased. Many families, of course, carry instalment debt on more than one commodity; comparison of the frequency of debt for all commodity groups (Table 7) with that for all families reporting a net change in 15 With one exception, electric refrigerators at the $\$ 500-750$ income level.

\section{TABLE 5}

Percentage Distribution of All Instalment-Debt Changes and of Increases and Decreases in Instalment Debt, 1935-1936, by Commodities ${ }^{1}$

\begin{tabular}{|c|c|c|c|}
\hline COMMODITY & $\begin{array}{c}\text { ALL } \\
\text { INSTALMENT- } \\
\text { DEBT CHANGES }\end{array}$ & $\begin{array}{l}\text { INCREASES } \\
\text { IN DEBT }\end{array}$ & $\begin{array}{c}\text { DECREASES } \\
\text { IN DEBT }\end{array}$ \\
\hline Automobiles & 20.0 & 22.5 & 14.6 \\
\hline Furniture & 31.4 & 27.0 & 41.2 \\
\hline Electric refrigerators & 15.4 & $14 \cdot 5$ & 17.4 \\
\hline Radios & 8.2 & 9.4 & 5.8 \\
\hline Other electric equipment & 15.2 & 15.9 & 13.5 \\
\hline Miscellaneous commodities & 9.8 & 10.7 & $7 \cdot 5$ \\
\hline Total & 100.0 & $1 \infty .0$ & 100.0 \\
\hline $\begin{array}{c}\text { Estimated total debt chang } \\
\text { (in thousands of units) }\end{array}$ & 3,799 & 2,618 & $I, 18 I$ \\
\hline
\end{tabular}

1Based on data from metropolises and large and middle-size cities; the estimates of all debt changes do not cover changes for families living in small cities or villages, or on farms. 


\section{National Bureau of Economic Research}

debt ${ }^{16}$ indicates that as income rises there is an increasing tendency for families to be indebted for more than one commodity at a time. At the $\$_{3000}$ level this trend is reversed.

For all commodities except automobiles more than nine out of ten families indebted for instalment purchases had incomes of less than $\$ 3000$, and eight out of ten families indebted for automobiles had incomes not exceeding this amount (Table 8). There were, however, marked differences in the commodityburing behavior of various income groups. Thus while 25-30 per cent of families using instalment credit for purchases of furniture, radios, and miscellaneous commodities had incomes below $\$ 1000$, this income group embraced only 6,9 , and 15 per cent of families indebted for automobiles, electric refrigerators, and 'other electric equipment' respectively. Again, though families with incomes under $\$ 2000$ accounted for 76,82 , and 73 per cent of the instalment-debt changes for furniture, radio, and miscellaneous commodities respectively, only 46 per cent of families indebted for automobiles, $\sigma_{5}$ per cent of those making instalment payments on refrigerators, and $\sigma_{7}$ per cent of those. paying for 'other electric equipment' were under this limit.

These differences seem to indicate a fairly consistent relationship berween commodity price, purchaser's income, and the use of instalment credit to finance the purchase. Automobiles, which sell at high unit prices, were purchased on instalment mainly by

${ }^{16}$ These data too apply only to metropolises and large and middle-size cities. They are not presented in this Bulletin.

Chart VI

PERCENTAGE DISTRIBUTION OF NET INCREASE IN INSTALMENT DEBT, 1935-1936, BY COMMODITIES

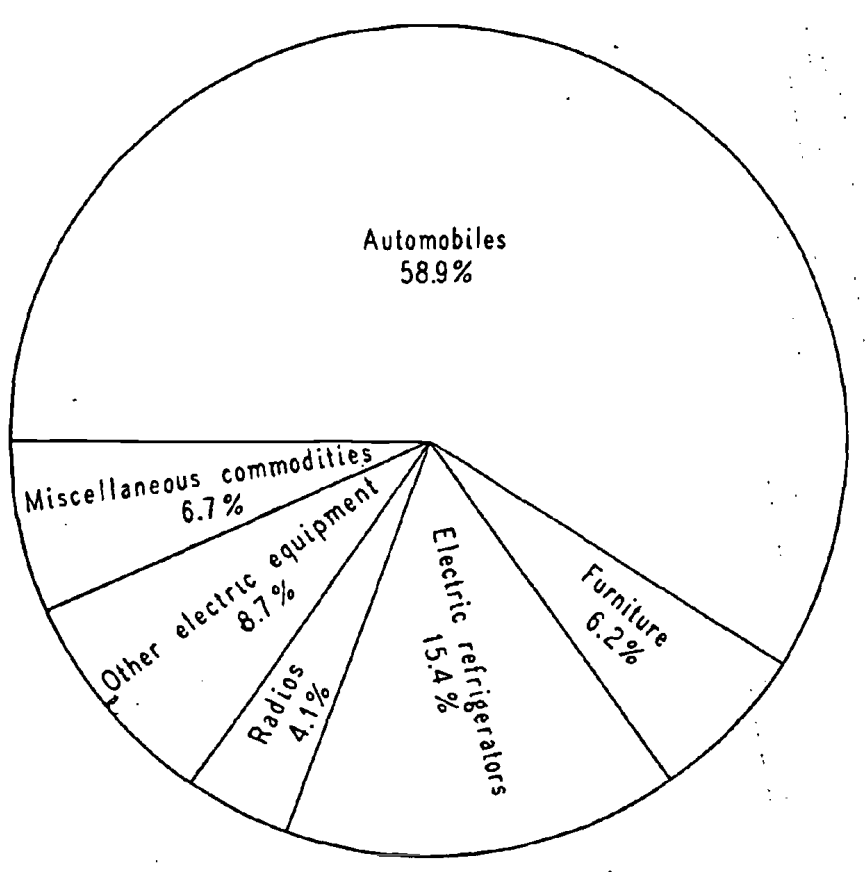

the middle and higher income families. Electric refrigerators, also bearing relatively high unit prices, were purchased more often by medium than by higher income groups. Radios, on the other hand, which may sell for as little as $\$ 7$ or $\$ 8$, were bought on instalment less of ten than any other commodity, and principally by low income families. The wider dispersion of instalment purchasers of furniture, 'other electric equipment', and miscellaneous commodities, throughout all income levels, is probably due to the greater range of articles within each of these groups and to the wide price differences based on quality. In short, higher priced furniture is purchased on instalment by a higher income group than is lower priced furniture.

\section{The Pattern of Increases and Decreases in Instal- ment Debt by Income Groups}

More families per hundred of population were increasing and more were decreasing instalment debts for furniture than for any other commodity (Table 9). But a smaller percentage of all families making instalment payments for furniture increased their obligations than of those paying on other commodities. While less than 60 per cent of the families indebted for furniture increased their debts, the percentages for other commodities ranked: about 77 per cent for automobiles and radios; 72 per cent for 'other electric equipment'; 76 per cent for miscellaneous commodities; and 64 per cent for electric refrigerators. The relatively low ratios for furniture and electric refrigerators may result from the fact that they are usually sold on longer terms than other commodities.

For each commodity the ratio of families increasing debt to those decreasing debt was higher in the lower income bands, and gradually decreased with each rise in income. ${ }^{17}$ In the income groups below $\$ 2000$ this ratio was above average, and it was

17The ratio for radios was an exception, however; it declined to the $\$ 2000$ level and then rose almost steadily as income increased. But less than 18 per cent of radio instalment buyers had incomes above this level, and only 8 per cent had incomes above $\$ 2500$.

\section{TABLE 6}

Percentage Distribution of Gross Increase, Gross Decrease, and Net Increase in Instalment Debt, I935-1936, by Commodities ${ }^{1}$

\begin{tabular}{lccc}
\hline \multicolumn{1}{c}{ COMMODITY } & $\begin{array}{c}\text { GROSS } \\
\text { INCREASE }\end{array}$ & $\begin{array}{c}\text { GROSS } \\
\text { DECREASE }\end{array}$ & $\begin{array}{c}\text { NET } \\
\text { INCREASE }\end{array}$ \\
Automobiles & 50.5 & 36.7 & 58.9 \\
Furniture & 17.8 & 37.1 & 6.2 \\
Electric refrigerators & 14.6 & 13.2 & 15.4 \\
Radios & 3.4 & 2.1 & 4.1 \\
Other electric equipment & 7.8 & 6.3 & 8.7 \\
Miscellaneous commodities & 5.9 & 4.6 & 6.7 \\
Total $\quad 1$ & 100.0 & 100.0 & 100.0 \\
\hline
\end{tabular}

'Based on data from metropolises and large and middle-size cities. The net increase is the difference between the gross increase and the gross decrease in the obligations due on each commodity. 


\section{The Statistical Pattern of Instalment Debt}

\section{TABLE 7}

Percentage of Non-Relief Families having a Net Change in Debt for the Instalment Purchase of Six Types of Commodities, 1935-1936, by Income Level ${ }^{1}$

\begin{tabular}{|c|c|c|c|c|c|c|}
\hline ANNLAL INCOME & $\begin{array}{l}\text { AUTO- } \\
\text { MOBILES }\end{array}$ & $\begin{array}{l}\text { FLRNI- } \\
\text { TURE }\end{array}$ & $\begin{array}{c}\text { ELECTRIC } \\
\text { REFRIG- } \\
\text { ERATORS }\end{array}$ & RADIOS & $\begin{array}{c}\text { OTHER } \\
\text { ELECTRJC } \\
\text { EQUIPACENT }\end{array}$ & $\begin{array}{l}\text { LUSCEL- } \\
\text { LANEOUS } \\
\text { COMARODITIES }\end{array}$ \\
\hline Under $\$ 250$ & .2 & 10.9 & .3 & 1.7 & 1.9 & 2.1 \\
\hline $250-500$ & .3 & I 1.3 & .6 & 2.4 & 2.0 & 2.4 \\
\hline $500-750$ & 1.3 & $13 \cdot 1$ & 1.0 & $5 \cdot 4$ & 2.7 & 4.6 \\
\hline $750-1000$ & $3 \cdot 4$ & I 5.6 & 4.0 & 3.7 & 5.1 & $3 \cdot 9$ \\
\hline $1000-1250$ & 4.8 & 13.7 & 6.1 & 4.6 & 6.8 & 4.8 \\
\hline $1250-1500$ & 6.1 & $13 \cdot 5$ & 6.3 & $3 \cdot 3$ & 7.2 & 4.1 \\
\hline $1500-1750$ & 7.8 & 13.1 & 8.9 & $3 \cdot 5$ & 6.4 & 2.9 \\
\hline $1750-2000$ & IO.I & II.9 & 9.6 & 3.6 & 7.6 & 4.7 \\
\hline $2000-2500$ & 12.5 & 10.9 & 8.6 & 2.5 & 6.5 & 3.6 \\
\hline $2500-3000$ & 14.5 & 11.2 & $7 \cdot I$ & 1.6 & 8.2 & 2.9 \\
\hline $3000-4000$ & I 2.6 & 8.0 & $5 \cdot 7$ & 1.4 & $4 \cdot 9$ & 3.1 \\
\hline $4000-5000$ & I 1.4 & 6.0 & 4.6 & .9 & $4 \cdot 2$ & $3 \cdot 3$ \\
\hline 5000 and over & 9.2 & 2.3 & .9 & -3 & 1.9 & 1.6 \\
\hline Total & $7 \cdot 5$ & I I. 8 & 5.9 & 3.1 & 5.8 & $3 \cdot 7$ \\
\hline
\end{tabular}

IBased on data from metropolises and large and middle-size cities.

lower than average above that level, suggesting that the increase in instalment buying attendant on expanding business activity during 1935-36 was, for all commodities, greater among lower than among higher income classes. This is more striking when it is noted (Table 8) that most families indebted for instalment purchases received annual incomes of less than $\$ 2000 .^{18}$ This ${ }^{18} \mathrm{As}$ has been pointed out, however, the majority of families indebted for instalment purchases of automobiles were in the higher income bands.
TABLE 8

Percentage Distribution of Non-Relief Families having a Net Change in Debt for the Instalment Purchase of Six Commodities, 1935-1936, Cumulated by Income Level ${ }^{1}$

\begin{tabular}{|c|c|c|c|c|c|c|c|}
\hline $\begin{array}{l}\text { ANNEAL } \\
\text { INCONE }\end{array}$ & $\begin{array}{l}\text { AUTO- } \\
\text { MOBILES }\end{array}$ & $\begin{array}{l}\text { FURNI- } \\
\text { TURE }\end{array}$ & $\begin{array}{l}\text { EIECTRIC } \\
\text { RESRIG- } \\
\text { ERATORS }\end{array}$ & RADIOS & $\begin{array}{c}\text { OTHER } \\
\text { ELECTRIC } \\
\text { EQUIP- } \\
\text { MENT }\end{array}$ & $\begin{array}{l}\text { MISCEL- } \\
\text { LANEOUS } \\
\text { COAIMOD- } \\
\text { ITIES }\end{array}$ & $\begin{array}{l}\text { ALL NON- } \\
\text { RELLEP } \\
\text { FAMILIES }\end{array}$ \\
\hline Under $\$ 5 \infty$ & .2 & 5.9 & .5 & 4.3 & 2.2 & 3.9 & 6.2 \\
\hline $500-750$ & 1.5 & I 4.1 & 1.8 & 17.2 & $5 \cdot 7$ & 13.2 & 13.6 \\
\hline $750-1000$ & 6.3 & 28.3 & 9.2 & 30.0 & I 5.3 & 24.6 & 24.4 \\
\hline $1000-1250$ & I 4.2 & 42.6 & 22.2 & 48.3 & 29.9 & 40.7 & 36.7 \\
\hline $1250-1500$ & 23.1 & 55.1 & 34.1 & 60.0 & $43-7$ & 52.9 & 47.7 \\
\hline $1500-1750$ & 33.6 & 66.3 & 49.6 & 71.4 & 55.0 & 60.9 & 57.8 \\
\hline $1750-2000$ & 45.8 & $75 \cdot 5$ & 64.6 & 82.0 & 67.1 & 72.6 & 66.9 \\
\hline $2000-2500$ & 66. I & 86.9 & 82.5 & 92.1 & 80.9 & 84.7 & 79.1 \\
\hline $2500-3000$ & 79.6 & 93.6 & وI.I & 95.7 & 91.0 & 90.3 & 86. I \\
\hline $3000-4000$ & 90.6 & 97.9 & 97.5 & 98.8 & 96.7 & 95.8 & 92.7 \\
\hline $4000-5000$ & 94.1 & 99.1 & 99.3 & 99.5 & 98.4 & 97.9 & 95.1 \\
\hline 5000 and ove & 100.0 & 100.0 & 100.0 & 100.0 & 100.0 & 100.0 & 100.0 \\
\hline
\end{tabular}

1 Based on data from metropolises and large and middle-size cities. Table 8 was derived from Table 7 by multiplying, for each income group, the number of non-relief families by the percentage of such families owing instalment debt, thus obtaining the number of families indebted and their distribution.

same tendency for income groups below $\$ 2000$ to increase their instalment debt more than families above that level during this year of cyclical expansion is reflected in Table 10.19 $\mathrm{O}_{\mathrm{n}}$ the

19It should be noted, however, that the data deal with only a part of the cyclical upswing. No data are available to indicate during which cyclical phase another income group exhibits a greater tendency to increase instalment debt.

Chart VIl

\section{PERCENTAGE OF NON-RELIEF FAMILIES HAVING A NET CHANGE IN DEBT FOR THE INSTALMENT PURCHASE OF SIX COMMODITIES, 1935-1936, BY INCOME LEVEL}

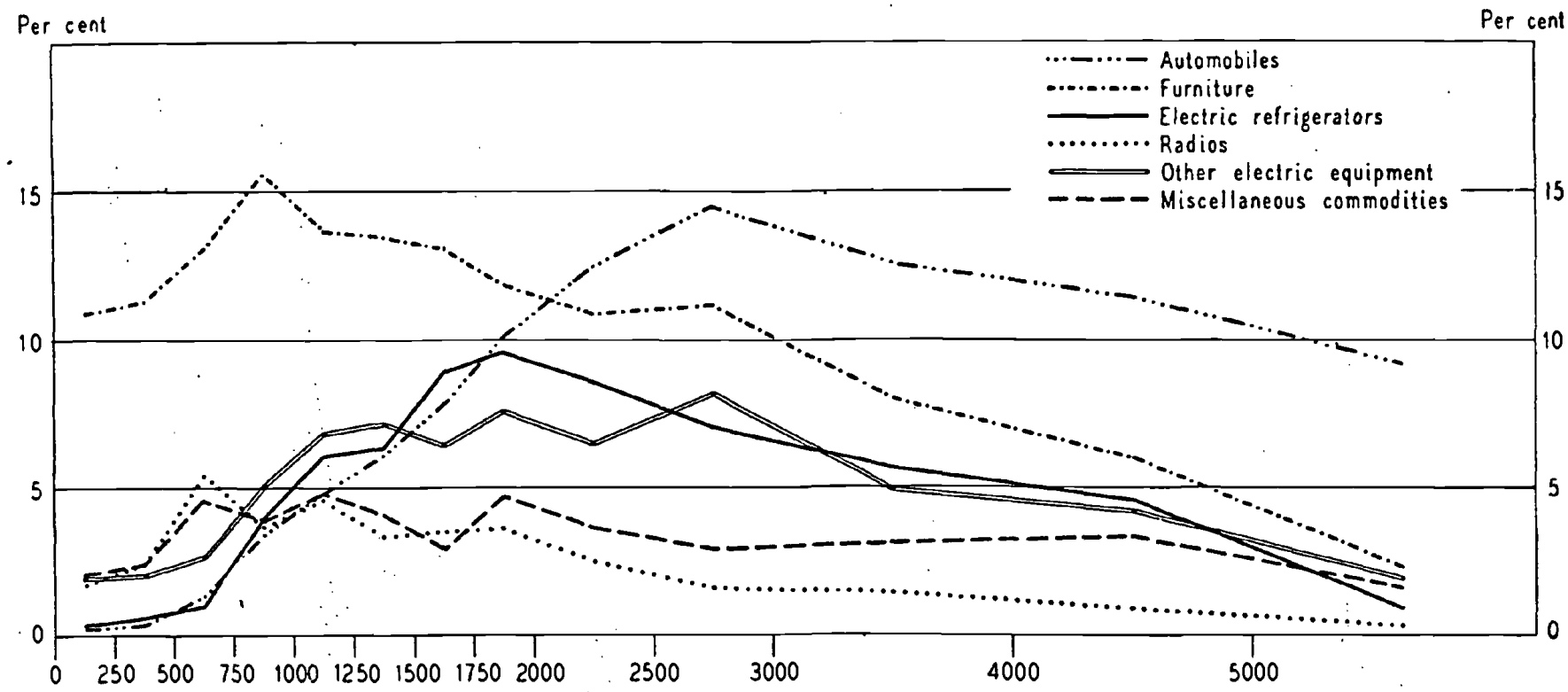

Income level in dollars 


\section{National Bureau of Economic Research}

TABLE 9

Percentage of Non-Relief Families Increasing or Decreasing Instalment Debt for Six Commodities, 1935-1936, by Income Level ${ }^{1}$

\begin{tabular}{|c|c|c|c|c|c|c|c|c|c|c|c|c|}
\hline \multirow{2}{*}{$\begin{array}{l}\text { ANNLAL } \\
\text { INCONE }\end{array}$} & \multicolumn{2}{|c|}{ AL“TOMOBJLES } & \multicolumn{2}{|c|}{ FLIRAITLRE } & \multicolumn{2}{|c|}{$\begin{array}{c}\text { ELECTRIC } \\
\text { REFRIGERATORS }\end{array}$} & \multicolumn{2}{|c|}{ RADIOS } & \multicolumn{2}{|c|}{$\begin{array}{l}\text { OTHER FLECTRIC } \\
\text { EQUIPMENT }\end{array}$} & \multicolumn{2}{|c|}{$\begin{array}{l}\text { MISCELLANEOLS } \\
\text { COMMODITIES }\end{array}$} \\
\hline & Increase & Decrense & Increase & Decrease & Increase & Decrease & Increase & Decrease & Increase & Decrease & Increase & Decrease \\
\hline Under $\$ 500$ & $\cdot 3$ & .0 & 7.5 & 3.6 & .4 & .2 & 2.0 & .2 & 1.3 & .7 & 2. I & .2 \\
\hline $500-1000$ & 2.1 & .5 & 8.1 & 6.4 & 2.0 & .8 & $3 \cdot 7$ & .8 & $3 \cdot 3$ & .8 & 3.6 & .6 \\
\hline $1000-1500$ & $4 \cdot 3$ & 1.1 & 8.1 & 5.5 & $4 \cdot 4$ & 1.8 & $3 \cdot 1$ & .9 & 5.2 & 1.9 & 3.2 & 1.3 \\
\hline $1500-2000$ & $7 \cdot 3$ & 1.6 & 7.9 & 4.6 & 6.0 & $3 \cdot 3$ & 2.5 & 1.0 & 5.1 & J.9 & 2.9 & .8 \\
\hline $2000-2500$ & 9.8 & 2.7 & 6.3 & 4.6 & 5.5 & 3.1 & 1.8 & .7 & $4 \cdot 7$ & 1.8 & 2.6 & 1.0 \\
\hline $2500-3000$ & 10.5 & 4.0 & 6.7 & 4.5 & $3 \cdot 9$ & 3.2 & 1.3 & $\cdot 3$ & $5 \cdot 3$ & 2.9 & 2.0 & .9 \\
\hline $3002-4000$ & 8.7 & $3 \cdot 9$ & $4 \cdot 3$ & $3 \cdot 7$ & $3 \cdot 3$ & 2.4 & 1.3 &. $\mathrm{I}$ & $3 \cdot 4$ & 1.5 & I.8 & 1.3 \\
\hline$+000-: 000$ & 8.2 & 3.2 & 2.8 & 3.2 & 1.5 & 3.1 & .7 & .2 & 2.3 & 1.9 & 2.7 & .6 \\
\hline 5000 and over & 7.2 & 2.0 & 1.3 & 1.0 & .5 & .4 & $\cdot 3$ & .0 & 1.2 & 7 & .9 & .7 \\
\hline Total & 5.8 & 1.7 & 7.0 & 4.8 & 3.8 & 2.1 & 2.4 & $\cdot 7$ & 4.2 & 1.6 & 2.8 & .9 \\
\hline
\end{tabular}

${ }^{1}$ Based on data from metropolises and large cities and middle-size cities.

whole, income groups under $\$ 2000$ included larger proportions of all families increasing debt than of all families decreasing debt. ${ }^{20}$ For instance, almost 50 per cent of families increasing automobile debts, but less than 40 per cent of those decreasing such debts, had incomes below $\$ 2000$. This tendency was not so marked, however, for furniture; for radios it held good only up to the $\$ 1000$ level, but, in contrast to most commodities, it reappeared after the $\$_{25} 500$ level.

For every commodity class except furniture increases by debtincreasing families exceeded, on the whole, decreases by debtdecreasing families (Table I 1 ). This tendency may reflect differences in the average age of instalment debt; it also suggests that

${ }^{20}$ Special exceptions in some income bands are to be noted: e.g., the $\$ 500-1000$ band in the case of furniture; the $\$ 1000-1500$ band in the case of miscellaneous commodities. unit purchases were for somewhat larger amounts or quantities during the expansion year $1935-36$ than in the preceding year. As between types of commodities marked differences in average amounts of increase or decrease are apparent, arising mainly from the different unit prices of the items purchased; for example, average increase and average decrease were largest for automobiles and smallest for radios. Table in suggests that lower income families that use instalment credit buy goods of lower unit prices than do higher income families. For commodities that carry high unit prices, such as automobiles and electric refrigerators, the average increase in instalment debt was, in all income levels, related directly to income; for other commodities it showed this relationship up to the $\$ 3000-4000$ level. A similar relationship obtained between average decrease and income, though for all commodity classes except furniture there was a

TABLE 10

Percentage Distribution of Non-Relief Families Increasing or Decreasing Instalment Debt for Six Commodities, 1935-1936, by Income Level ${ }^{1}$

\begin{tabular}{|c|c|c|c|c|c|c|c|c|c|c|c|c|}
\hline \multirow{2}{*}{$\begin{array}{l}\text { ANXUAL } \\
\text { INCOME }\end{array}$} & \multicolumn{2}{|c|}{ AUTOMOBILES } & \multicolumn{2}{|c|}{ FUR NITURE } & \multicolumn{2}{|c|}{$\begin{array}{c}\text { ELECTRIC } \\
\text { REFRIGERATORS }\end{array}$} & \multicolumn{2}{|c|}{ RADIOS } & \multicolumn{2}{|c|}{$\begin{array}{l}\text { OTHER ELECTRIC } \\
\text { EQUIPMENT }\end{array}$} & \multicolumn{2}{|c|}{$\begin{array}{l}\text { MISCELLANEOUS } \\
\text { COMMODITIES }\end{array}$} \\
\hline & Increase & Decrease & Increase & Decrease & Increase & Decrease & Increase & Decrease & Increase & Decrease & Increase & Decrease \\
\hline Under $\$ \$ \infty$ & $\cdot 3$ & .0 & 6.7 & $4 \cdot 7$ & .5 & .5 & 5.1 & 1.9 & 1.9 & 2.8 & 4.7 & 1.5 \\
\hline $500-1000$ & 6.2 & 6.0 & 21.1 & $24 \cdot 5$ & 9.5 & 7.2 & $27 \cdot 3$ & 20.0 & 14.6 & 90 & 23.6 & 11.5 \\
\hline $1000-1500$ & 17.3 & $I_{4} .8$ & 26.9 & 26.7 & 27.2 & 20.6 & 29.7 & 31.1 & 29.0 & 27.1 & 26.9 & 33.2 \\
\hline $1500-2000$ & 23.9 & 18.4 & 21.7 & 18.4 & 30.5 & 30.6 & 20.0 & 29.0 & $23 \cdot 7$ & 22.8 & 20.1 & 18.1 \\
\hline $2000-2500$ & 20.5 & 19.5 & 11.1 & 11.7 & 17.8 & 18.2 & 9.3 & 12.9 & 13.7 & $14 \cdot 3$ & 11.6 & $13 \cdot 5$ \\
\hline $2500-3000$ & 12.7 & 16.5 & 6.7 & 6.6 & $7 \cdot 3$ & 11.0 & 3.7 & 3.1 & 9.0 & 12.8 & 5.1 & 7.2 \\
\hline $3000-4000$ & 9.9 & 14.8 & 4.0 & 4.9 & 5.7 & $7 \cdot 5$ & 3.6 & 1.3 & $5 \cdot 4$ & 6.3 & 4.2 & 9.6 \\
\hline $4000-5000$ & 3.2 & $4 \cdot 3$ & .9 & 1.5 & .9 & 3.5 & .7 & .7 & 1.3 & 2.8 & 2.2 & 1.6 \\
\hline 5000 and over & 6.0 & 5.7 & .9 & 1.0 & .6 & .9 & .6 & .0 & I. 4 & 2.1 & 1. 6 & 3.8 \\
\hline Total & 100.0 & 100.0 & 100.0 & 100.0 & 100.0 & 100.0 & $100.0 !$ & 100.0 & 100.0 & 100.0 & 100.0 & 100.0 \\
\hline
\end{tabular}

IBased on data from metropolises, large cities and middle-size cities. 


\section{The Statistical Pattern of Instalment Debt}

level of income at which a reversal of the tendency occurred. This again would seem to confirm the observation that the use of instalment credit is associated mainly with commodity purchases at prices and in quantities compatible with the family's income.

Table 12 shows, for the several groups of commodities, the distribution of estimated gross increase and gross decrease in instalment debt; it indicates that approximately half of both the gross increase and the gross decrease was attributable to the income groups between $\$ 1000$ and $\$ 2000$-except for automobiles, where the share approximated a third of the increase and a fourth of the decrease. Between a fourth and a third of gross increase and decrease was attributable to income groups between $\$_{2000}$ and $\$_{3000}$, but above this level and below the $\$ 1000$ level widely varying proportions obtained. While families with incomes of less than $\$ 1000$ originated approximately 20 and 24 per cent of the gross increase in furniture and radio debts, respectively, they created only 9 per cent of the increase in electric refrigerator debt and less than 3 per cent of the increase in automobile debt. For every commodity except automobiles and the miscellaneous group, only a minor share of gross increase or decrease originated with families having incomes above $\$ 4000$, and below $\$ 500$ the share was minor for every type of commodity.

In general, for all commodities except radios, the lower income groups (those below the $\$ 2000$ level) were responsible for a larger proportion of the gross increase than of the gross decrease in debt. Conversely, higher income families had a relatively larger share of the gross decrease. In the case of radios, families in income groups below $\$ 1500$ and above $\$ 2500$ had larger proportions of gross increase, whereas those between these levels had a larger share of gross decrease.

It is important to note also (from a comparison of Tables ro and 12) that the share of gross increase or decrease in debt attributable to lower income families was less than proportionate to the number of debt-increasing or debt-decreasing families in these bands. For example, 77 per cent of all families increasing furniture debts had incomes below $\$ \mathbf{2 0 0 0}$, but these families created only 69 per cent of the gross increase in such debt. On the other hand, in the higher income levels the share of the gross increase or decrease was more than proportionate to the number of families; in the case of auromobiles the income bands above $\$ 2000$ included 52 per cent of the families increasing debt and $\sigma_{2}$ per cent of the gross increase in automobile debt. In the lower income levels, however, there was a comparatively greater concentration of families increasing obligations and of the gross increase in debt. Table 13 shows that, except for automobile purchases, by far the largest part of the increased instalment debt outstanding at the end of the period 1935-36 was the result of purchases made by lower-income families. Thus the distribution of the net increase was more nearly proportionate to the distribution of families having a change in instalment debt (Table 8), except in the case of furniture, where almost the entire net increase occurred in income levels below $\$ 2000$.

\section{The Pattern of Instalment Debt by Types of Com- MUNITIES}

Families receiving equivalent incomes but living in different types of communities vary considerably in instalment-debt behavior. Table I4, based on data covering the instalment purchases of all commodities combined, indicates that in $1935-36$ the frequency of instalment debt was greatest in urban communities. One out of every three families living in large cities, just under this number in middle-size and small cities, and one out of five metropolitan families, ${ }^{21}$ were indebted for instalment purchases. Debt occurred in one out of four village families${ }^{21}$ Metropolitan families are defined as those living within the city limits of metropolises.

TABLE II

Average Increase and Decrease in Instalment Debt Incurred by Non-Relief Families in the Purchase of Six Commodities, 1935-1936, by Income Level ${ }^{1}$

\begin{tabular}{|c|c|c|c|c|c|c|c|c|c|c|c|c|}
\hline \multirow{2}{*}{$\begin{array}{l}\text { ANNUAL } \\
\text { INCOME }\end{array}$} & \multicolumn{2}{|c|}{ AUTOMOBILES } & \multicolumn{2}{|c|}{ FURNITURE } & \multicolumn{2}{|c|}{$\begin{array}{c}\text { ELECTRIC } \\
\text { REFRIGERATORS }\end{array}$} & \multicolumn{2}{|c|}{ RADIOS } & \multicolumn{2}{|c|}{$\begin{array}{l}\text { OTHER ELECTRIC } \\
\text { EQUIPMENT }\end{array}$} & \multicolumn{2}{|c|}{$\begin{array}{l}\text { MISCELLANEOUS } \\
\text { COMMODITIES }\end{array}$} \\
\hline & Increase & Decrease & Increase & Decrease & Increase & Decrease & Increase & Decrease & Increase & Decrease & Increase & Decrease \\
\hline Under $\$ 5 \infty$ & $\$ 33$ & $\$-$ & $\$ 44$ & $\$ 56$ & $\$ 87$ & $\$ 37$ & $\$ 33$ & $\$ 10$ & $\$ 16$ & $\$ 23$ & $\$ 20$ & \\
\hline $500-1000$ & III & 129 & 59 & 58 & 109 & 47 & 30 & $2 I$ & $4^{8}$ & 33 & 43 & 17 \\
\hline $1000-1500$ & I 77 & 125 & 72 & 70 & 109 & 65 & 44 & 30 & 49 & 37 & 54 & 48 \\
\hline $1500-2000$ & 257 & 202 & $8 \mathrm{I}$ & 90 & II 5 & 72 & 44 & 42 & 59 & $4^{8}$ & $6 I$ & 65 \\
\hline $2000-2500$ & 265 & 271 & 91 & III & 122 & 79 & “ 53 & 53 & 70 & 50 & 98 & 73 \\
\hline $2500-3000$ & 288 & 263 & 106 & 153 & 120 & 76 & 59 & $3^{8}$ & 63 & 52 & 103 & 55 \\
\hline $3000-4000$ & 320 & 294 & 115 & 128 & 126 & 89 & 50 & 21 & 72 & 45 & 171 & 75 \\
\hline $4000-5000$ & 382 & 439 & 82 & 131 & 158 & 89 & 29 & 64 & 71 & 48 & II 8 & 106 \\
\hline 5000 and over & 416 & 335 & 118 & 298 & 156 & 72 & 30 & - & 53 & 75 & 129 & $I_{49}$ \\
\hline Total & 259 & $24^{2}$ & $7^{6}$ & 86 & 115 & 73 & $4 I$ & 35 & 56 & 44 & 66 & $5^{8}$ \\
\hline
\end{tabular}

'Based on data from metropolises and large and middle-size cities. 'Average increase' refers to families having an increase, and 'average decrease' to those having a decrease in debt. 


\section{National Bureau of Economic Research}

slightly more often than among those in metropolitan areasand only one out of nine farm families had instalment debt.

The less extensive use of instalment credit by families living in metropolises compared with those living in other cities is in part due to less frequent ownership of automobiles. Higher automobile operating costs and the greater adequacy of transport facilities, as well as the higher cost of living in general, are the primary factors which operate against automobile ownership in metropolitan areas. ${ }^{22}$

The lower prevalence of debt among farm families can probably be traced to the irregular flow of agricultural income, which militates against a credit plan calling for regular monthly payments over a long period. Besides this, farmers, as entrepreneurs, tend to intermix production and consumption finance, and to obtain their credit accommodation more frequently from specialized farm credit agencies. ${ }^{23}$ Instalment buying by farm families is confined mainly to automobiles and farm equipment, and it is facilitated by special contracts adjusted to the irregularity of farm income.

Table ${ }_{4} 4$ and Chart VIII show by income levels the preva22In this connection see How Urban Families Spend Their Incomes (July 1938), a study by the U. S. Bureau of Labor Statistics, Table ${ }_{9} \mathrm{C}$. 23It is also possible that farm families make use of the easy payment plans of mail order houses to a greater extent than city families, and use this short-term financing as a substitute for longer-term instalment credit. lence of instalment debt in each type of community. Generally speaking, it rose with income to the $\$ 2000$ level, then tapered off through the higher income brackets; but in large cities the decline did not set in until the $\$ 3000$ income level, and in farm communities the peak was not reached until the \$2500-3000 level. In each income class under $\$ 5000$ the frequency of debt was highest among families in large cities, ${ }^{2 \downarrow}$ where instalment debt was owed by more than one-fifth of families with incomes below $\$ 500$ and by almost two-fifths of families with incomes of $S_{1} 500$ to $\$ 3000$. Families who lived in small cities ranked second in frequency of debt up to $\$ 3000$, after which those in mediumsize cities took second rank. Village families ranked fourth up to about the same level.

Metropolitan families with incomes below $\$_{1000}$ made little more use of instalment credit than did farm families with equivalent income; and only a little more than one-fifth of metropolitan families with incomes of $\$ 1000$ to $\$ 3000$ had instalment debt. It is interesting to note that instalment debt among farm families was more general in income levels above $\$ 2000$ (where it averaged about one-sixth) than it was for families below this level.

Table i 5, representing a special analysis, by commodities, of families indebted for instalment purchases in the North Central region, indicates that in the urban communities of this region

24 With the exception of the $\$ 1500-2000$ income level, where frequency of debt was slightly higher in small cities.

TABLE I 2

Percentage Distribution of Gross Increase and Gross Decrease in Instalment Debt for Six Commodities, 1935-1936, by Income Level ${ }^{1}$

\begin{tabular}{|c|c|c|c|c|c|c|c|c|c|c|c|c|}
\hline \multirow{2}{*}{$\begin{array}{l}\text { ANNUAL } \\
\text { INCOME }\end{array}$} & \multicolumn{2}{|c|}{ ALTOMOBILES ${ }^{2}$} & \multicolumn{2}{|c|}{ FURNITURE } & \multicolumn{2}{|c|}{$\begin{array}{c}\text { ELECTRIC } \\
\text { REFRIGERATORS }\end{array}$} & \multicolumn{2}{|c|}{ RADIOS } & \multicolumn{2}{|c|}{$\begin{array}{l}\text { OTHER ELECTRIC } \\
\text { EQLIPMENT }\end{array}$} & \multicolumn{2}{|c|}{$\begin{array}{l}\text { MISCELLANEOUS } \\
\text { COMMODITIES }\end{array}$} \\
\hline & Increase & Decrease & Increase & Decrease & Increase & Decrease & Increase & Decrease & Increase & Decrease & Increase & Decrease \\
\hline Under $\$ 5 \infty$ & 3 & .0 & 3.9 & 3.0 & -4 & .2 & 4.1 & .5 & .5 & 1.5 & I. 5 & .I \\
\hline $500-1000$ & 2.7 & 3.1 & 16.4 & 16.4 & 9.0 & $4 \cdot 7$ & 20.0 & 11.9 & I 2.6 & 6.7 & II. 3 & $3 \cdot 4$ \\
\hline $1000-$ I 500 & I 1.8 & $7 \cdot 7$ & 25.4 & 21.6 & $25 \cdot 5$ & 18.6 & 31.8 & $27 \cdot 3$ & 25.2 & 22.8 & 22.7 & $27 \cdot 4$ \\
\hline $1500-2000$ & 23.8 & I 5.4 & $23 \cdot 3$ & I9.2 & 30.4 & 30.5 & 21.5 & 35.1 & $24 \cdot 7$ & 24.9 & 19.4 & 20.5 \\
\hline $2000-2500$ & 21.0 & 21.9 & 13.1 & I 5.0 & 18.7 & 20.0 & I. 1.9 & 19.7 & 17.1 & 16.1 & 18.0 & 16.9 \\
\hline $2500-3000$ & I 4.1 & I 8.1 & 9.4 & 11.7 & 7.6 & 11.6 & $5 \cdot 4$ & $3 \cdot 4$ & IO.I & 15.0 & 8.2 & 6.7 \\
\hline $3000-+\infty 00$ & 12.2 & 18.0 & 6.1 & $7 \cdot 3$ & 6.2 & 9.2 & $4 \cdot 4$ & .8 & 6.9 & 6.4 & 11.5 & 12.4 \\
\hline $4000-5000$ & 4.8 & 7.9 & 1.0 & 2.3 & J. 3 & $4 \cdot 3$ & .5 & $\mathrm{~J} \cdot 3$ & 1.6 & 3.0 & 4.2 & 2.8 \\
\hline 5000 and over & 9.6 & 7.9 & 1.4 & $3 \cdot 5$ & .9 & .9 & .4 & .0 & , I.3 & 3.6 & 3.2 & 9.8 \\
\hline Total & 100.0 & $1 \infty 0.0$ & 100.0 & 100.0 & 100.0 & $1 \infty 0.0$ & 100.0 & 100.0 & 100.0 & 100.0 & 100.0 & 100.0 \\
\hline $\begin{array}{l}\text { Estimated total } \\
\text { change (in } \\
\text { millions) }\end{array}$ & I 52.1 & $4^{I} \cdot 4$ & 53.5 & 41.9 & 43.8 & 14.9 & 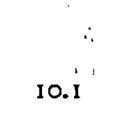 & 2.3 & $23 \cdot 5$ & 7.1 & 17.8 & 5.2 \\
\hline
\end{tabular}

1 Based on data from metropolises and large and middle-size cities. Therefore the estimates of total change do not represent the total change in instalment debt for the country as a whole. 'Gross increase' refers to families having an increase in debt and 'gross decrease' to those having a decrease.

2The reader must be cautioned against comparing these estimates of automobile instalment debt, derived from the Consumer Purchases data, with estimates that may be derived from the U. S. Department of Commerce figures on automobile instalment sales, for the two sets of data are different in nature and coverage.

${ }^{3}$ Less than .05 per cent. 


\section{The Statistical Pattern of Instalment Debt}

furniture purchases were the most frequent base of instalment debt, while in villages and on farms automobile purchases were most important. Automobiles were second most important in urban centers, 'other electric equipment' third, and electric refrigerators fourth.

Table 16 , also applying to communities in the North Central region, indicates the distribution, among the various types of communities, of families indebted for each of the six commodities. Large and small cities are shown to have included the largest percentage of instalment debtors of all commodities except the miscellaneous group. Although only one-third of the population of the region lives in large and small cities, these communities together included 50 per cent or more of the families indebted for furniture, electric refrigerators, radios, and 'other electric equipment', and 43 per cent of families indebted for the instalment purchases of automobiles.

On the other hand, the proportion of instalment debtors that lived in metropolises tended to be smaller than the metropolitan share of regional population, except that the proportion indebted for furniture and miscellaneous items slightly exceeded the metropolitan share of population. There was some variation in middle-size cities. They were relatively well represented among families indebted for electric refrigerators and 'other electric equipment' and slightly under-represented in miscellaneous instalment purchases, but they had about a proportionate number of families indebted for purchases of automobiles, furniture, and radios:

The villages' share of families indebted for instalment pur-

\section{TABLE I3}

Percentage Distribution of Net Increase in Instalment Debt for Six Commodities, 1935-1936, by Income Level ${ }^{1}$

\begin{tabular}{|c|c|c|c|c|c|c|}
\hline $\begin{array}{l}\text { ANNOAI } \\
\text { LVCONIE }\end{array}$ & $\begin{array}{l}\text { AVTO- } \\
\text { MOBIIES }\end{array}$ & $\begin{array}{c}\text { FURNI- } \\
\text { TURE }\end{array}$ & $\begin{array}{l}\text { ELECTRIC } \\
\text { REFRIG- } \\
\text { ERATORS }\end{array}$ & RADIOS & $\begin{array}{c}\text { OTHER } \\
\text { ELECTRIC } \\
\text { EQUTRSENT }\end{array}$ & $\begin{array}{c}\text { MISCEL- } \\
\text { LANEOUS } \\
\text { COMMODITIES }\end{array}$ \\
\hline Under $\$ 500$ & .1 & 7.1 & .5 & 5.1 & .1 & 2.0 \\
\hline $500-1000$ & 2.5 & 16.4 & II.I & 22.4 & I 5.1 & 14.5 \\
\hline $1000-1500$ & 13.4 & 39.5 & 29.2 & 33.2 & 26.2 & 20.9 \\
\hline $1500-2000$ & 26.9 & 38.0 & 30.5 & 17.5 & 24.7 & 18.9 \\
\hline $2000-2500$ & 20.7 & 6.5 & 18.1 & 9.6 & 17.5 & 18.5 \\
\hline $2500-3000$ & 12.7 & 1.2 & $5 \cdot 5$ & 6.0 & 8.0 & 8.8 \\
\hline $3000-4000$ & 9.9 & 1.2 & 4.6 & 5.4 & $7 \cdot 1$ & 11.2 \\
\hline $4000-5000$ & 3.6 & 2 & 3 & .2 & 1.0 & $4 \cdot 7$ \\
\hline 5000 and over & IC. 2 & 2 & .8 & .6 & $\cdot 3$ & .5 \\
\hline Total & 100.0 & $100.0^{2}$ & $100.0^{3}$ & 100.0 & 100.0 & 100.0 \\
\hline $\begin{array}{l}\text { Estimated net } \\
\text { increase (in } \\
\text { millions) }\end{array}$ & 110.8 & II. 6. & 28.9 & 7.8 & $16: 4$ & 12.6 \\
\hline
\end{tabular}

${ }^{1}$ Based on data from metropolises and large and middle-size cities. The estimates of the net increase in outstandings do not represent the total net increase for the country as a whole.

${ }^{2}$ The total is actually 109.9 per cent because there was a net decrease in debt in the $\$ 4000-5000$ income levels ( 3.8 per cent) and in the $\$ 5000$ and over (6.I per cent).

${ }^{3}$ The total is actually 100.3 per cent because of a net decrease in debt in the $\$ 4000-5000$ income level of 0.3 per cent. chases of automobiles, 'other electric equipment' and miscellaneous commodities was roughly in proportion to their share of population, but they were under-represented among families indebted for furniture, electric refrigerators, and radios. Farm families, constituting 17 per cent of the regional population, did not have instalment debt for any commodity commensurate with their numerical importance in the population, although in the case of automobiles and miscellaneous commodities the disproportion was slight. The extremely low percentage of farm families among buyers of electric appliances is due in large measure to the lack of electric power facilities in farm areas.

\section{Regional Differences in the Use of Instalment Credit}

The use of instalment credit varies not only with types of communities but also with geographic regions. Table 17, which is based on data from all types of communities in five major regions, shows that the frequency of instalment debt was highest in the Pacific region, where practically one out of every three families had such debt, compared with one out of four families in the Southern, New England, and Mountain-and-Plain regions, and one out of five in the North Central region. ${ }^{25}$ The frequency of debt in the North Central region was influenced, of course, by the low frequency of debt obtaining in metropolitan centers in this area.

Comparison by income levels brings out other regional differences which are shown in Chart IX. The lead of the Pacific region in prevalence of debt obtained generally only at income levels below \$2000; above this level the frequency of debt was greatest in the South and was particularly striking for families above the $\$ 4000$ income level, of whom about one-fourth had instalment debt. The highèst frequency of debt in the Pacific region was 42 per cent, occurring in the $\$ 1500-2000$ income group; in the South it was 4I per cent, in the $\$ 2000-2500$ income group.

The Mountain-and-Plain region ranked third in instalment indebtedness above the $\$ 750$ level, with 35 per cent indebted in the \$1500-2000 band; the New England peak was 27 (\$10001500) and that of the North Central region was 25 (\$1 500-2000). The North Central region (embracing the more populous industrial states) had the lowest frequency of debt in every income band up to $\$ 2000$, and above that level New England had a slightly lower debt frequency.

Also for individual commodities the prevalence of instalment debt varied considerably by geographic region. Table i8, based on data covering metropolises, large cities, and middle-size cities, shows that in each commodity group, except miscellaneous items, debt frequency was higher in the Pacific region and in the South than it was in the country as a whole. In New England it

${ }^{25}$ This table, showing the percentage of families having a net change in instalment debt in each income level, does not reveal the influence of the varying distributions of income in the different regions on regional variations in the use of instalment credit. The figures for the total percentage of families indebted in each region do, however, reflect these varying income distributions. See also Table 19 , footnote $\mathrm{I}$. 


\section{National Bureau of Economic Research}

was somenthat higher for furniture and miscellaneous merchandise, but lomer for other commodities. In the Mountain-andPlain region it rias slightly lower than average for electric refrigerators, higher for others. For all commodity groups instalment debr in the North Central states was below the average in frequency.

\section{TABLE I4}

Percentage of Non-Relief Families in Different Types of Communities having a Net Change in Instalment Debt, 1935-1936, by Income Level ${ }^{1}$

\begin{tabular}{|c|c|c|c|c|c|c|c|}
\hline $\begin{array}{l}\text { ANDLAL } \\
\text { INCONEE }\end{array}$ & $\begin{array}{l}\text { METROP- } \\
\text { OLIIEST }\end{array}$ & $\begin{array}{l}\text { LARGE } \\
\text { CITJES }\end{array}$ & $\begin{array}{c}\text { MIDDLE- } \\
\text { SIRE } \\
\text { CITIES }\end{array}$ & $\begin{array}{l}\text { SMALLL } \\
\text { CITIES }\end{array}$ & VILLAGES & FARUS & $\begin{array}{l}\text { ALL COM- } \\
\text { MUNITIES }\end{array}$ \\
\hline Under $\$: \infty$ & $3 \cdot 1$ & 20.5 & 12.9 & 17.5 & II. 8 & 8.2 & 11.9 \\
\hline $500-1000$ & 11.7 & 30.2 & 23.6 & 26.9 & 22.0 & 9.9 & 19.2 \\
\hline $1000-1500$ & 20.2 & $3+\cdot 3$ & 32.2 & 35.8 & 26.1 & 12.3 & 26.1 \\
\hline $1500-2000$ & 22.6 & 39.5 & 37.1 & 37.4 & 31.0 & 13.9 & 30.2 \\
\hline $2000-2500$ & 21.2 & $39 \cdot 5$ & $33 \cdot 7$ & 33.9 & 30.1 & 17.0 & 30.2 \\
\hline $2500-3000$ & $23 \cdot 3$ & 39.4 & 30.1 & $3^{1.6}$ & 26.2 & 17.9 & 29.3 \\
\hline $3000-4000$ & 22.0 & 32.0 & 25.4 & 21.6 & 21.6 & 13.4 & 23.8 \\
\hline$+000-5000$ & 16.2 & 25.6 & 24.9 & 20.1 & 2.3 .6 & 15.1 & 21.5 \\
\hline 5000 and over & $1 \hat{3} \cdot 3$ & 14.0 & 14.1 & 16.2 & 17.9 & 17.3 & 15.0 \\
\hline Total & 18.6 & 33.6 & 28.3 & 30.5 & 24.0 & 11.5 & 23.6 \\
\hline
\end{tabular}

1. Wetropolises, 1,500,000 population and over; large cities, 100,000 to I, $5 \infty, 000$; middile-size cities, 25,000 to $100, \infty 00$; small cities, 2,500 to $25, \infty 00$; villages, less than 2,500 .
The prevalence of furniture, refrigerator, and radio debt was greatest in the Soudh. One out of five Southern families had furniture debt, one out of eight had refrigerator debt, and one out of trienty had radio debt. This might suggest that Southern families were buying these household items-both for cash and on instalment-more frequently than were families elsewhere; other family expenditure data available from the Study of Consumer Purchases, however, fail to show any striking regional differences in expenditure for household furnishing and equipment. ${ }^{26}$ These figures therefore seem to indicate a tendency among Southern families to purchase such commodities on instalment rather than for cash.

Frequency of instalment debt for automobiles was highest in the Mountain-and-Plain region; one out of seven families in this region had such debt, compared with one out of nine in the Pacific and Southern regions and one out of seventeen in New England and North Central states. The expenditure data referred to above ${ }^{27}$ show that in the latter two regions a smaller percentage of families bought cars in $1935-36$, and that proportionately fewer families owned cars, than in the West and South. These regional differences in the pattern for instalment purchases

26Bureau of Labor Statistics, How Urban Families Spend Their Incomes (July 1938), Tables $8 \mathrm{~A}$ and $8 \mathrm{~B}$.

${ }^{27}$ Ibid., Tables $9 \mathrm{~A}$ and $9 \mathrm{C}$.

Chart VIII

PERCENTAGE OF NON-RELIEF FAMILIES IN DIFFERENT TYPES OF COMMUNITIES HAVING A NET CHANGE IN INSTALMENT DEBT, 1935-1936, BY INCOME LEVEL

Per cent

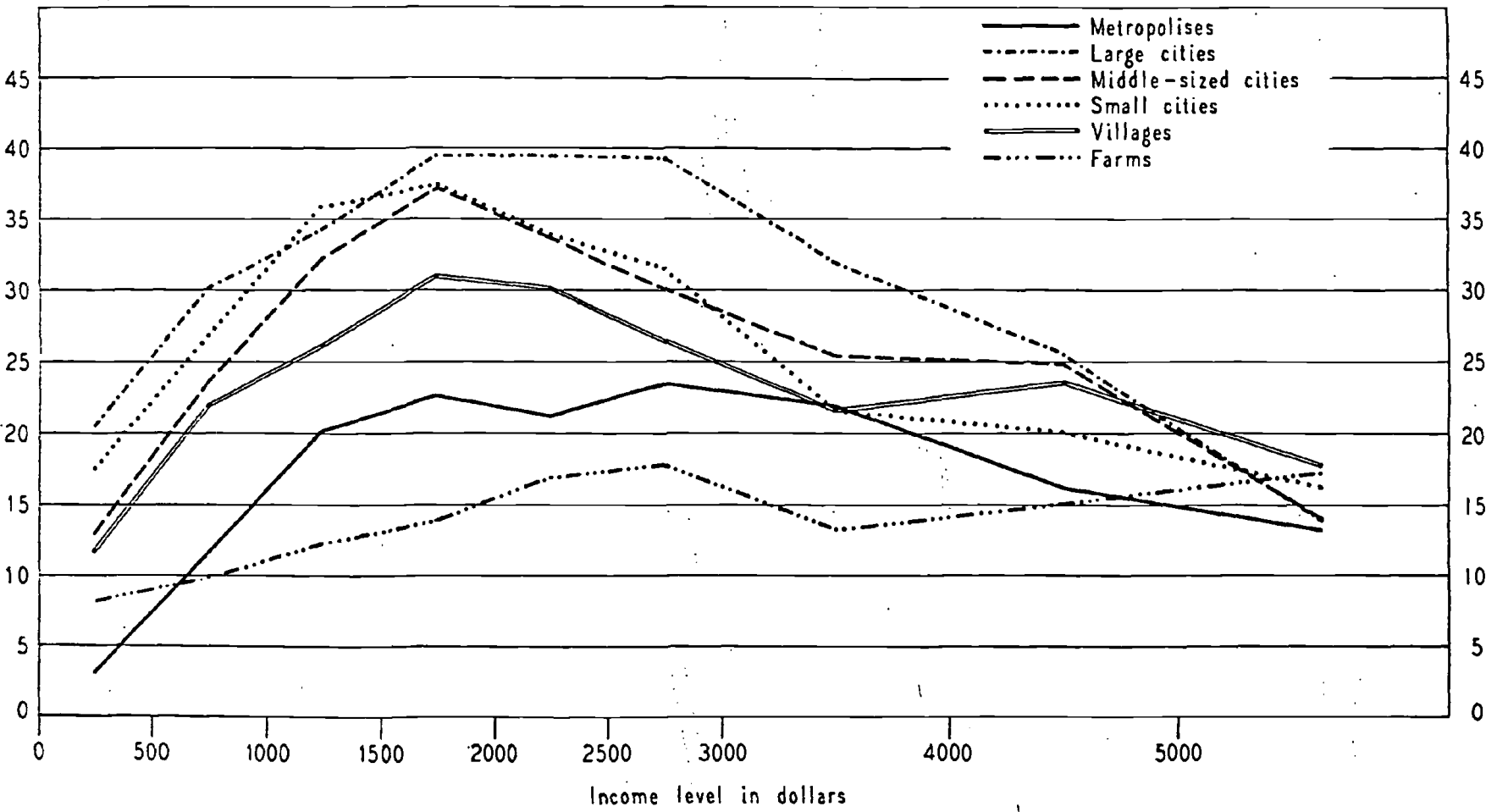




\section{The Statistical Pattern of Instalment Debt}

\section{TABLE I 5}

Percentage of Non-Relief Families in the North Central Region having a Net Change in Debt for the Instalment Purchase of Six Commodities, 1935-1936, by Type of Community

\begin{tabular}{|c|c|c|c|c|c|c|}
\hline $\begin{array}{l}\text { TSPE OF } \\
\text { CONAIUNITY }\end{array}$ & $\begin{array}{l}\text { AVTO- } \\
\text { IOBILES }\end{array}$ & $\begin{array}{l}\text { TLRTI- } \\
\text { TERE }\end{array}$ & $\begin{array}{c}\text { ELECTRIC } \\
\text { REFRIG- } \\
\text { ERATORS }\end{array}$ & RADIOS & $\begin{array}{l}\text { OTHER } \\
\text { ELECTRIC } \\
\text { EQUIP. }\end{array}$ & $\begin{array}{l}\text { MISCEL- } \\
\text { LANEOLIS } \\
\text { COMODITIES }\end{array}$ \\
\hline Metropolises & 3.8 & 7.6 & 3.0 & 1.8 & 3.0 & 3.8 \\
\hline Large cities & 8.4. & 12.8 & 5.6 & 2.9 & 6.4 & 3.8 \\
\hline \multicolumn{7}{|l|}{ Middle-size } \\
\hline cities & 6.5 & $7 \cdot \cdot 4$ & 5.0 & 1.7 & 5.1 & 2.9 \\
\hline Small cities & 8.1 & $9 \cdot 5$ & $5 \cdot 9$ & 2.6 & 6.6 & 3.1 \\
\hline Villages & 6.8 & 3.0 & 2.2 & 1.2 & 3.7 & 4.7 \\
\hline Farms & 5.7 & .6 &.$I$ & .9 & .2 & $3 \cdot 4$ \\
\hline
\end{tabular}

of automobiles reflect higher living costs in the North Central and New England regions, as well as the fact that families in heavily populated areas have less need for automobile transportation than families in regions of more scattered population.

Table in, which presents, by commodities, the regional distribution of families indebted for instalment purchases, shows that well over two-fifths of families indebted for commodities in the five main groups, and three-fifths of families indebted for miscellaneous products, lived in the North Central region. Even these high proportions are low compared to the general popula-
TABLE I 6

Percentage Distribution of Non-Relief Families in the North Central Region having a Net Change in Debt for the Instalment Purchase of Six Commodities, 1935-1936, by Type of Community

\begin{tabular}{|c|c|c|c|c|c|c|c|}
\hline $\begin{array}{l}\text { TYPE OF } \\
\text { COMMLNITY }\end{array}$ & $\begin{array}{l}\text { AUTO- } \\
\text { SIOBILES }\end{array}$ & $\begin{array}{l}\text { FURN1- } \\
\text { TURE }\end{array}$ & $\begin{array}{l}\text { ELECTRIC } \\
\text { REFRIG- } \\
\text { ERATORS }\end{array}$ & RADIOS & $\begin{array}{l}\text { OTHER } \\
\text { ELECTRIC } \\
\text { EQCIP- } \\
\text { MIENT }\end{array}$ & $\begin{array}{l}\text { MISCEL- } \\
\text { LANEELS } \\
\text { COSSIOD- } \\
\text { ITIES }\end{array}$ & $\begin{array}{l}\text { ALL, NOS- } \\
\text { RELIEF } \\
\text { FAMILLES }\end{array}$ \\
\hline Metropolises & $\begin{array}{ll}5 & 13.6\end{array}$ & 25.2 & 19.4 & 22.0 & 16.9 & 23.7 & 22.8 \\
\hline Large cities & 22.1 & 31.4 & 26.7 & 26.2 & 26.7 & 17.5 & 16.8 \\
\hline \multicolumn{8}{|l|}{ Middle-size } \\
\hline cities & 11.5 & 12.2 & 16.0 & 10.3 & $I+3$ & 9.0 & 11.3 \\
\hline Small cities & 21.1 & 23.0 & 27.9 & $23 \cdot 3$ & 27.2 & 14. I & I 6.6 \\
\hline Villages & 16.3 & 6.7 & $9 \cdot 5$ & 9.8 & 14.0 & 19.6 & $15 \cdot 3$ \\
\hline Farms & $15 \cdot 4$ & 1.5 & .5 & 8.4 & .9 & 16.1 & $1 \% \cdot 2$ \\
\hline Total & 100.0 & 100.0 & 100.0 & 100.0 & 100.0 & 100.0 & 100.0 \\
\hline
\end{tabular}

tion, for this region contains more than three-fifths of all urban non-relief families.

The South had the second largest share of instalment debtors, its proportion ranging from i 6 per cent of the families who bought miscellaneous articles to 35 per cent of the families who bought refrigerators. The proportion was in each case (except miscellaneous purchases) larger than the Southern share of the urban population.

In all groups except miscellaneous products the Pacific region

Chart IX

\section{PERCENTAGE OF NON-RELIEF FAMILIES IN DIFFERENT REgIONS HAVING A NET CHANGE IN INSTALMENT DEBT, 1935-1936, BY INCOME LEVEL}

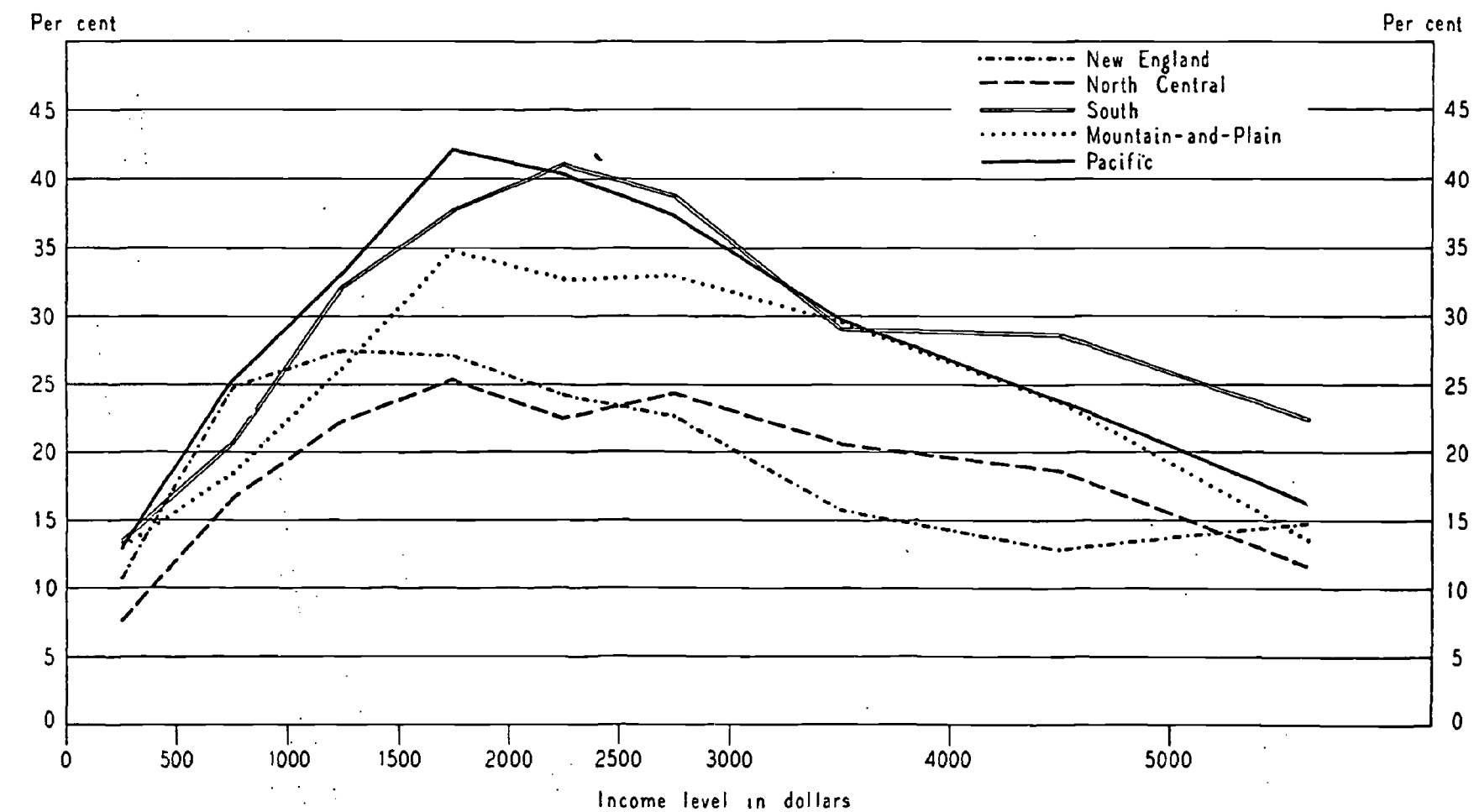




\section{National Bureau of Economic Research}

TABLE I7

Percentage of Nion-Relief Families in Different Regions ${ }^{1}$ having a Net Change in Instalment Debt, 1935-1936, by Income Level

\begin{tabular}{|c|c|c|c|c|c|c|}
\hline $\begin{array}{l}\text { ANTYL } \\
\text { INCONEE }\end{array}$ & $\begin{array}{l}\text { NEW } \\
\text { ENGLAND }\end{array}$ & $\begin{array}{c}\text { NORTH } \\
\text { CENTRAL }\end{array}$ & SOUTH & $\begin{array}{l}\text { MOLTTAIN- } \\
\text { AND-PLAIN }\end{array}$ & pACIFIC & $\begin{array}{c}\text { ALL } \\
\text { REGIONS }\end{array}$ \\
\hline Lnder $\$ 5 \infty$ & 10.7 & 7.6 & $13 \cdot 3$ & 13.0 & 13.0 & 11.9 \\
\hline $500-1000$ & $=4.7$ & 16.5 & 20.6 & 18.4 & 25.2 & 19.2 \\
\hline $1000-1 ; 00$ & $=7.5$ & 22.3 & 32.1 & 26.2 & 33.6 & 26.1 \\
\hline $1500-2000$ & $=7.1$ & 25.4 & 37.6 & $3+.8$ & 42.1 & 30.2 \\
\hline $2000-2500$ & $24 \cdot 3$ & 22.5 & $4^{1.0}$ & 32.7 & 40.3 & 30.2 \\
\hline $2500-3000$ & 22.7 & 24.4 & $3^{8.8}$ & 33.0 & $37 \cdot 4$ & 29.3 \\
\hline $3000-4000$ & 15.7 & 20.6 & 29.0 & 29.5 & 29.7 & $=3.8$ \\
\hline $4000-5000$ & I 2.8 & 18.7 & 28.8 & $=3.6$ & $=3.7$ & 21.5 \\
\hline 5000 and over & $1+.8$ & II. 6 & 22.4 & 13.5 & 16.2 & 15.0 \\
\hline Total & $24 \cdot 3$ & 20.3 & 25.9 & 24.6 & 32.6 & 23.6 \\
\hline
\end{tabular}

New England: Connecticut, Maine, Massachusetts, New Hampshire, Rhode Island, Vermont

North Central: Illinois, Indiana, Iowa, Michigan, Minnesota, Missouri, New Jersey, New York, Ohio, Pennsylvania, Wisconsin South: Alabama, Arkansas, Delaware, Florida, Georgia, Kentucky; Louisiana, Maryland, Mississippi, North Carolina, Oklahoma, South Carolina, Tennessee, Texas, Virginia, West Virginia

Mountain-and-Plain: Arizona, Colorado, Idaho, Kansas, Montana, Nebraska, Nevada, New Mexico, North Dakota, South Dakota, Litah, Wyoming

Pacific: California, Oregon, Washington.

had the third largest share of instalment debtors; it included onetenth of all furniture debtors and almost one-fifth of 'other electric equipment' debtors, although less than a tenth of the urban families reside in this region. New England and the Mountainand-Plain states contributed the smallest percentages of families
TABLE 18

Percentage of Non-Relief Families having a Net Change in Debt for the Instalmeni Purchase of Six Commodities, 1935-1936, by Region ${ }^{1}$

\begin{tabular}{|c|c|c|c|c|c|c|}
\hline REGION & $\begin{array}{l}\text { AUTO- } \\
\text { MYBILES }\end{array}$ & $\begin{array}{l}\text { FERNT- } \\
\text { TURE }\end{array}$ & $\begin{array}{l}\text { ELrCTRIC } \\
\text { REFRIG- } \\
\text { ERATORS }\end{array}$ & RADIOS & $\begin{array}{c}\text { OTHER } \\
\text { ELECTRIC } \\
\text { ERCIPAENT }\end{array}$ & $\begin{array}{l}\text { MISCEL- } \\
\text { IANEOLIS } \\
\text { COMAODITIES }\end{array}$ \\
\hline New England & 6.0 & 12.9 & 3.1 & 2.6 & $3 \cdot 9$ & 4.2 \\
\hline Corth Central & 5.9 & 9.2 & +3 & 2.2 & 4.5 & 3.6. \\
\hline $\begin{array}{l}\text { South } \\
\text { Yountain-and }\end{array}$ & II.O & 19.9 & 11.9 & 5.7 & 7.4 & 3.6 \\
\hline Plain & 15.2 & $1+.6$ & 5.6 & $3 \cdot 5$ & 9.6 & 5.8 \\
\hline Pacific & 11.0 & I 2.5 & 7.8 & 4.5 & II. 2 & $3 \cdot 4$ \\
\hline Total & 7.5 & 11.8 & 5.9 & 3.1 & 5.8 & $3 \cdot 7$ \\
\hline
\end{tabular}

${ }^{1}$ Based on data from metropolises and large and middle-size cities.

indebted for the instalment purchase of each commodity, ${ }^{2 s}$ the shares being roughly in proportion to urban population in these regions.

In each region more than two out of three families having instalment debt were increasing their debts during the expansion year 1935-36. Table 20, presenting distributions, by six commodity groups, of families having increases or decreases in instalment obligations, indicates a tendency in the populous and highly urbanized North Central region for a proportionately greater number of families to increase than decrease debt for all commodities except furniture and radios. In the South, on the other hand, a considerably larger proportion of families were

2:With one exception, miscellaneous merchandise, for which the Pacific region had the second lowest per cent and New England the third lowest.

TABLE I9

Percentage Distribution of Non-Relief Families having a Net Change in Debt for the Instalment Purchase of Six Commodities, $1935-1936$, by Region ${ }^{1}$

\begin{tabular}{|c|c|c|c|c|c|c|c|}
\hline REGION & AUTOMOBILES & FURNITURE & $\begin{array}{c}\text { ELECTRIC } \\
\text { REFRIGERATORS }\end{array}$ & RADIOS & $\begin{array}{c}\text { OTHER } \\
\text { ELECTRIC } \\
\text { EQIIPMENT }\end{array}$ & $\begin{array}{l}\text { MISCELLANEOUS } \\
\text { COMMODITIES }\end{array}$ & $\begin{array}{c}\text { ALI } \\
\text { NON-RELIEF } \\
\text { FAMIIIIES }\end{array}$ \\
\hline New England & 6.8 & . 9.2 & $4 \cdot 4$ & 7.0 & 5.6 & 9.5 & 8.4 \\
\hline North Central & 48.8 & 48.8 & 45.8 & $43 \cdot 4$ & 49.5 & 60.9 & 62.2 \\
\hline South & 24.9 & 28.6 & 34.5 & 31.4 & 21.8 & 16.4 & 17.1 \\
\hline Mountain-and-Plain & 5.6 & $3 \cdot 4$ & 2.7 & 3.1 & +6 & $4 \cdot 3$ & 2.8 \\
\hline Pacific & 13.9 & 10.0 & 12.6 & 15.1 & 18.5 & 8.9 & 9.5 \\
\hline Total & 100.0 & 100.0 & 100.0 & 100.0 & 100.0 & 100.0 & 100.0 \\
\hline
\end{tabular}

IBased on data from metropolises and large and middle-size cities. Therefore the influence of the varying prevalence of village and farm communities in the different regions does not affect the regional differences shown in this table. Since regional variations in instalment-debt behavior during $1935-36$ are shown to exist, and since approximately 70 per cent of all instalment-debt families are urban inhabitants, it would appear that there were also variations in consumer instalment-debt response as between similar types of communities in different regions. The data which furnished the basis for our preceding analysis of debt-change by type of community were drawn only from the North Central region. Types of communities in the South, for example, would be expected to have patterns of cyclical response for different commodity groups conforming, with variations among communities, to that shown here for the region as a whole.

It will be possible, on the basis of data now in preparation, to present a comparison of the use of instalment credit by income levels in the same type of community in different regions, so that the influence of regional location on the use of instalment credit can be viewed more directly. ${ }^{2}$ Adapted from Consumer Incomes in the United States, Apperidix B, Table ${ }_{2}+\mathrm{B}$. 


\section{The Statistical Pattern of Instalment Debt}

TABLE 20

Percentage Distribution of Non-Relief Families Increasing or Decreasing Instalment

Debt for Six Commodities, 1935-1936, by Region ${ }^{1}$

\begin{tabular}{|c|c|c|c|c|c|c|c|c|c|c|c|c|}
\hline \multirow{2}{*}{ REGION } & \multicolumn{2}{|c|}{ ALTOMOBILES } & \multicolumn{2}{|c|}{ FURNITURE } & \multicolumn{2}{|c|}{$\begin{array}{c}\text { F.LECTRIC } \\
\text { REFRIGERATORS }\end{array}$} & \multicolumn{2}{|c|}{ RADIOS } & \multicolumn{2}{|c|}{$\begin{array}{c}\text { OTHER ELECTRIC } \\
\text { EQUIPMENT }\end{array}$} & \multicolumn{2}{|c|}{$\begin{array}{l}\text { MISCELLANEOUS } \\
\text { COMMODITIES }\end{array}$} \\
\hline & Increase & Decrease & Increase & Decreáse & Increase & Decrease & Increase & Decrease & Increase & Decrease & Increase & Decrease \\
\hline New England & 6.5 & $7 \cdot 4$ & 8.5 & 10.3 & $4 \cdot 4$ & 4.5 & 6.9 & 7.2 & 5.9 & . 5.3 & 10.4 & 6.7 \\
\hline North Central & 50.3 & 43.9 & 48.1 & 49.1 & 49.2 & 39.1 & 43.6 & 44.7 & 51.1 & $43 \cdot 3$ & 61.7 & 56.9 \\
\hline $\begin{array}{l}\text { South } \\
\text { Mountain-and- }\end{array}$ & 23.8 & 29.1 & 30.8 & 25.9 & 29.7 & 43.8 & 32.4 & 27.0 & 20.6 & 25.9 & 17.5 & 13.6 \\
\hline $\begin{array}{l}\text { Mountain-and- } \\
\text { Plain }\end{array}$ & 5.2 & 6. & 3.5 & 3.3 & 2.7 & 2.5 & 2.6 & 4.7 & 4.3 & 5.6 & 3.7 & 7.6 \\
\hline Pacific & 14.2 & 12.9 & 9.1 & 11.4 & I 4.0 & 10. 1 & I 4.5 & 16.4 & 18.1 & 19.9 & 6.7 & 15.2 \\
\hline Total & 100.0 & 100.0 & 100.0 & 100.0 & 100.0 & 100.0 & 100.0 & 100.0 & 100.0 & 100.0 & 100.0 & 100.0 \\
\hline
\end{tabular}

${ }^{1}$ Based on data from metropolises and large and middle-size cities.

decreasing debts for automobiles, electric refrigerators and 'other electric equipment' than were increasing them. Other regions had, in four out of six commodity groups, a somewhat larger proportion of families decreasing than increasing debts, though in practically every case the difference was nominal.

Table 21, which distributes gross increase and decrease in debt for each commodity group by regions, shows how the tendencies noted above were reflected in the distribution of gross increase and gross decrease in debt. Families in North Central states incurred a larger proportion of gross increase than of decrease in instalment debt for all commodities except furniture, where they were responsible for 57 per cent of the total decrease and 50 per cent of the increase. The South incurred a larger share of gross decrease than of increase in debt for electric refrigerators, automobiles, radios, and miscellaneous products, and only in the case of furniture and 'other electric equipment' was the South responsible for a larger share of gross increase than of gross decrease in debt. The differences in the proportions of gross increase and decrease attributable to other regions were not striking, and conformed approximately to those for the distribution of families having increases or decreases.

During the year $1935-36$ each region incurred a net increase in total instalment debt for every one of the six commodity groups. Table 22 shows that North Central states originated about half or more of the net increase in debt for every commodity group except furniture, but only a quarter of the increase for furniture. The South accounted for more than half of the increase in furniture debt, and from a fifth to a fourth of the debt-increase for the other principal commodity groups. The Pacific region ranked second as a source of debt-increase for only one group, miscellaneous electric equipment, and was the third important source of debt for electric refrigerators, automobiles, and radios.

This analysis of changes in instalment debt by commodities

TABLE 2I

Percentage Distribution of Gross Increase and Gross Decrease in Instalment Debt - for Six Commodities, 1935-1936, by Region 1

\begin{tabular}{|c|c|c|c|c|c|c|c|c|c|c|c|c|}
\hline \multirow[t]{2}{*}{ REGION } & \multicolumn{2}{|c|}{ AUTOMOBILES } & \multicolumn{2}{|c|}{ FURNITURE } & \multicolumn{2}{|c|}{$\begin{array}{c}\text { ELECTRIC } \\
\text { REFRIGERATORS }\end{array}$} & \multicolumn{2}{|c|}{ RADIOS } & \multicolumn{2}{|c|}{$\begin{array}{c}\text { OTHER ELECTRIC } \\
\text { EQUIPMENT }\end{array}$} & \multicolumn{2}{|c|}{$\begin{array}{l}\text { MISCELLANEOUS } \\
\text { COMMODITIES }\end{array}$} \\
\hline & Increase & Decrease & Increase & Decrease & Increase & Decrease & Increase & Decrease & Increase & Decrease & Increase & Decrease \\
\hline New England & 5.9 & 5.9 & 7.8 & 7.8 & 5.2 & $\therefore \quad 5.0$ & 6.0 & 4.8 & 5.9 & 6.I & 8.0 & 5.2 \\
\hline North Central & 51.7 & $44 \cdot 3$ & 50.4 & 57.2 & $5 \mathrm{I} . \mathrm{I}$ & 43.6 & 50.7 & 42.7 & 45.5 & 45.1 & 65.9 & 59.2 \\
\hline $\begin{array}{l}\text { South } \\
\text { Mountain-and- }\end{array}$ & 21.8 & 30.0 & 27.7 & 20.7 & 29.0 & 39.5 & 27.6 & 34.5 & 20.9 & 19.3 & 13.2 & 15.8 \\
\hline Plain & 5.2 & 7.7 & $4 \cdot 4$ & 3.4 & 2.3 & 2.5 & 3.0 & 4.7 & 3.8 & $7 \cdot 1$ & 4.5 & 7.2 \\
\hline Pacific & $15 \cdot 4$ & I 2.1 & 9.7 & 10.9 & 12.4 & $9 \cdot 4$ & 12.7 & $13 \cdot 3$ & 23.9 & 22.4 . & 8.4 & I 2.6 \\
\hline Total & 100.0 & 100.0 & 100.0 & 100.0 & 100.0 & 100.0 & 100.0 & 100.0 & 100.0 & 100.0 & 100.0 & 100.0 \\
\hline
\end{tabular}

'Based on data from metropolises and large and middle-size cities. 


\section{National Bureau of Economic Research}

TABLE 22

Percentage Distribution of Net Increase in Instalment Debt for Six Commodities, 1935-1936, by Region ${ }^{1}$

\begin{tabular}{|c|c|c|c|c|c|c|}
\hline REGION & $\begin{array}{l}\text { AlTo- } \\
\text { MOBILES }\end{array}$ & $\begin{array}{l}\text { FURNI- } \\
\text { TURE }\end{array}$ & $\begin{array}{l}\text { ELECTRIC } \\
\text { REFRIC: } \\
\text { ERATORS }\end{array}$ & RADIOS & $\begin{array}{c}\text { OTHER } \\
\text { FLECTRIC } \\
\text { EQUIPYIENT }\end{array}$ & $\begin{array}{l}\text { MISCEL- } \\
\text { LAEOCS } \\
\text { COMNODISBES }\end{array}$ \\
\hline New England & 59 & 7.6 & 5.3 & 6.4 & 5.8 & 9.0 \\
\hline North Central & $5 \div 5$ & 25.3 & $5 \$ 0$ & 53.2 & 45.9 & 68.5 \\
\hline $\begin{array}{l}\text { South } \\
\text { Mountain-and }\end{array}$ & 18.7 & $53 \cdot 4$ & 2.3 .6 & 25.4 & 21.5 & 12.1 \\
\hline Plain & 4.2 & 8.2 & 2.1 & 2.5 & 2.3 & 3.5 \\
\hline Pacific & 16.7 & $5 \cdot 5$ & 17.0 & 12.5 & $24 \cdot 5$ & 6.9 \\
\hline Tot:al & 100.0 & 100.0 & 100.0 & 100.0 & 100.0 & 100.0 \\
\hline
\end{tabular}

Based on data from metropolises and large and middle-size cities. during a given period of business expansion suggests that there were substantial variations by geographic regions in the cyclical response of consumers toward debt. During this period the South liquidated instalment obligations on all commodities ex: cept furniture to a greater extent than any other region, whereas in the North Central region the prevailing tendency was toward an increase in instalment debt for all groups of commodities except furniture. Such variations reflect, of course, the combined play of many factors: the type of regional economy, agricultural or industrial; the stage of regional development; the distribution of regional family income; the degree of regional urbanization or population concentration; the regional lead in cyclical movements and the amount of regional business expansion; cultural or social attitudes toward debt; and perhaps many others.

\section{APPENDIX}

\section{Methods of Estimate and Limitations of the Data}

The expenditure data obtained from the Study of Consumer Purchases were based on a selected sample of 60,000 families drawn from a larger random sample of 300,000 families. The data supplied to the National Bureau by the two government agencies had already been weighted by the random sample weights, and all of the original field samples of each type of community and color-nativity group had been combined within each region to form some fifty basic tabulation units. The problem, then, of building up instalment-debt estimates for the country as a whole was to combine these fifty separate series into one overall tabulation. The process of combination may be illustrated in terms of the data showing the percentage of families increasing instalment debt.

In some types of communities data were available for six separate occupations; in others they were already combined into from two to five occupational groups. Data for each type of community were put on a uniform basis by combining the various occupations into two groups, using weights from the random sample of 300,000 families. One group comprised salaried and independent professional, salaried, and independent business and clerical workers; the other included only wage earners.

The first combination made was of data available from two samples of the same occupational and color-nativity group in one type of community within the same region. Data for non-relief families in each occupational group in New York and Chicago, and in small and middle-size cities in the East Central and West Central regions, ${ }^{1}$ were combined by obtaining an unweighted average in each income group. Farm data in regions other than the South were combined by weighting each percentage. by population weights provided by the National Resources Committee. ${ }^{2}$ Data for each color-nativity and farm status group in the South ${ }^{3}$ were combined by using unweighted averages. These 1The East and West Central regions together form the North Central. ${ }^{2}$ Thus the series of percentages representing North Central farms are a weighted average of the data for Pennsylvania and Ohio, Illinois and Iowa, and Michigan and $W_{\text {isconsin farms. }}$ unweighted color-nativity and farm status series were then consolidated by the use of population weights, resulting in a single series to represent Southern farms. The data for white and Negro families in each occupational group in the other degrees of urbanization in the South, and in the metropolises and large cities in the North Central region, were then combined by weighting the series for each color group by the appropriate population weights. ${ }^{4}$

Our final combinations were of data for each occupational group in each type of community in the five regions: metropolises, large cities, medium-size cities, small cities, villages, farms. The two occupational groups in each type of community were then combined and for each income group a weighted average of the percentage in the six degrees of urbanization was obtained which represents the United States as a whole. Tables showing a regional breakdown were developed separately by combining first the two occupational groups in each community within a region, and then by combining all the types of communities within each of the five regions.

In developing tables showing change in instalment balance due, that is, average increase or decrease, combinations were made by using unweighted averages in all cases where the percentages of the families having an increase or decrease in debt were initially derived in this way. Where weights were required, they were developed for both increases and decreases in debt by multiplying the population by the percentage of families having

3Separate tabulations were made for white operators, white sharecroppers, Negro operators, Negro sharecroppers, in North and South Carolina, and in Georgia and Mississippi farm counties and in North Carolina for 'self-sufficing' farmers.

4That are here called population weights are in effect the distributions of families in the United States by income level, color, and nativity, type of community and region. The income distributions of various groups of farm communities within regions have not been published, but were made available to us by the National Resources Committee. All other income distributions which we have used as weights can be found in Consumers' Incomes in the United States. 


\section{The Statistical Pattern of Instalment Debt}

an increase or decrease. Thus separate weights were obtained for each commodity group.

Tables showing the changes in instalnent debt incurred on individual commodities are confined to data from middle-size cities, large cities, and metropolises. Tables which show a breakdown by type of community and by commodity are derived from special tabulations which cover, in addition, small cities, villages and farms in the North Central region only. Our analysis of variations in the use of instalment credit for different commodities by type of community is therefore restricted to communities in the North Central region. These data on individual commodities are somen hat limited, and it is necessary to exercise some caution in extending the results to the country as a whole, for, as indicated in the text, the smaller communities have a different pattern of instalment debt from that of the larger communities.

Various limitations and difficulties are involved in the use of material from the Study of Consumer Purchases. The expenditure study included in its scope only families who had not received relief during any part of the year. Thus families on relief and single individuals, both relief and non-relief, were excluded from the data. The omission of relief families and of single persons receiving relief is probably not of great importance in a study of the use of instalment credit, since their low incomes and inferior credit rating bar them from most instalment purchases. Non-relief single individuals, however, are a significant group whose pattern of instalment debt may differ from that for families.

Another factor of some importance is the lack of data for foreign-born families. Separate estimates were not attempted for this group either, but on the assumption that its pattern of debt would not differ enough to affect the results greatly, the foreignborn white population was combined with the native white to weight the data for the latter group. Other color groups, an insignificant proportion of population, were added to the Negro population.

Data were lacking in some types of communities for the lowest income groups, and in others for the highest income groups. No figures were available, for instance, for native white families with incomes under $\$ 500$ in large cities and metropolises, or for families with incomes under $\$ 250$ in middle-size and small cities and villages, though such families were covered in farm counties. In some cases the data for all small-city families with incomes of $\$ 3000$ and more were combined. In regard to villages and farms data were generally lacking for the income groups over $\$ 10,000$.

The deficiencies of the data for the very low and high income groups necessitated special estimates of their debt patterns. One possible method was to extrapolate on the basis of the pattern for the intermediate income groups, using some mathematical equation to express a trend from which estimates for the omitted groups could be derived. This method was rejected, however, for three reasons: first, the error of estimate is large, even with the best mathematical procedure; second, because of the rela- tively smalier number of families included in individual tabulation units, the trend in some cases was not clear, making it difficult to choose an equation; third, the amount of labor entailed was considered too great.

Actually, families in the income bands for which estimates were required form less than 4 per cent of the total non-relief population, as well as a relatively insignificant proportion of the families in the particular communities for which estimates were made. Whatever the estimates, their effect on the pattern of instalment debt as a whole could be only slight. We therefore adopted a simpler and easier alternative.

In making estimates of the percentage of families in the lowest income band having an increase or decrease in instalment debt, we applied to the $\$ 250-500$ band the percentage change between the figures for that band and for the \$500-700 band, when at least a partial trend was evident. Where no trend was evident between the next higher income classes we arbitrarily borrowed the figure in the adjoining income group. Where no trend at all was apparent, the average of all income levels was used, but only to estimate the percentage of families having debt and not to estimate average amount of increase or decrease. In making the latter estimates the most frequent procedure employed was either to borrow the average of the next higher income level or to apply to the $\$ 250-500$ income group the percentage change between the averages for that group and for the $\$ 500-750$ group. It was sometimes necessary to make the estimate on the basis of the trend in another type of community or color-nativity group, but this was rarely done.

The final results thus obtained for the income class under $\$ 250$ and, to a lesser extent, for \$250-500, are only approximate, but they are sufficiently accurate to warrant their use, in view of the relative insignificance of the groups for which these estimates are being made. Tables which show the percentage distribution of families incurring instalment debt, as well as those which indicate the distribution of the debt burden among income levels, regions, types of communities or commodities, are affected only slightly by the quality of the estimates.

One other qualification of the data should be made. When the expenditure schedule was filled out the family was asked only if there had been a change, that is, either an increase or a decrease, in instalment debt as between the beginning and the end of the schedule year. Thus the data which represent the percentage of families having a net change in debt, or what we have called those indebted for instalment purchases, do not include families who, during the course of the year, contracted an additional amount of instalment debt exactly equal to the amount paid off. But this does not present a very serious drawback, especially since families reported even very small amounts of increase or decrease in debt. Because of the nature of the data, however, we were unable to include families who contracted and fully paid off instalment debt within the year period. We are therefore to some extent underestimating the number of families who made use of instalment credit or were indebted for instalment purchases during the year 1935-36. 


\section{National Bureau of Economic Research}

Ralph A. Young, Director of the Financial Research Project of the National Bureau, is Associate Professor of Economics and Chairman of the Department of Economics, Wharton School, University of Pennsylvania.

Blanche Bernstein is research assistant of the Financial Research Project staff of the National Bureau. Previously she wias a member of the Consumption research staff of the industrial section of the National Resources Committee.

\section{IN PRESS}

\section{Studies in Income and Wealth, Volume Three}

In contrast to the preceding two volumes, which were devoted primarily to problems centering about the meaning and measurement of total national income and wealth, the third volume is made up of papers concerned with problems centering about the division of a national total, of either weal th or income, into meaningful constituents. The first three papers deal with the division of the total among groups of income recipients or wealth holders classified by size of income or amount of wealth owned. The fourth is an attempt to estimate the portion of total income that is saved rather than used to purchase goods currently consumed. The fifth is a review of the available allocations of income by the kinds of goods and services that make up the total income stream and a plea for better measures in this field. The sixth considers the problems involved in allocating the total income of the nation among political units, the states; and the seventh, the usefulness of such an allocation for the purpose of measuring relative capacities of the states as a guide in distributing grants in aid. The titles and authors are:

\section{Part One}

American Studies of the Distribution of Wealth and INCOME BY SIZE

CHARLES L. MERWIN, JR.

Burenu of Foreign and Domestic Commerce

United States Department of Commerce

\section{Part Two}

Income Capitalization as a Method of Estimating the Distribution of Wealth by Size Groups

CHAR LES STEWART

Brooklyn College

\section{Part Three}

The Use of Income Tax Data in the National Resources Committee Estimate of the Distribution of INCOME BY SIZE

ENID BAIRD

Bureau of Foreign and Domestic Commerce United States Department of Commerce $A$ ND

SELMA FINE

National Resources Planning Board
Part Four

Volume and Components of Saving in the United States, 1933-1937

R. W. GOLDSMITH with the assistance of W. S. SALANT Securities and Exchange Commission

\section{Part Five}

Three Estimates of the Value of the Nation's Outpu'p of Commodities and Services-a Comparison

CLARK WARBURTON

Federal Deposit Insurance Corporation

Part Six

Some Problems Involved in Allocating Incomes by States ROBERT R. NATHAN

Bureau of Foreign and Domestic Commerce

United States Department of Commerce

Part Seven

Income and the Measurement of the Relative Capacities of the States

PAUL H. WUELLER

Pennsylvania State College

The commentators on these papers are: Simon Kuznets, Milton Friedman, Fritz Lehmann, Gerhard Colm, M. A. Copeland, E. L. Dulles, A. G. Hart, Harold Groves, A. J. Goldenthal, Gordon Keith, J. L. Martin, and Hans Neisser.

The price of Volume Three, which will consist of about 500 pages, will be $\$ 3.50$. Volume One, described in Bulletin 66 , sells for \$2.50; Volume Two, described in Bulletin $72-73$, for $\$ 3$. A special price of $\$ 7.50$ is offered on the three volumes together.

\section{PRICE SERIES}

Stephen J. Kennedy, Chairman of the Committee on Textile Price Research, has completeted his revision of the Committee's report which will be published before the end of the year as number 2 in the Price Series.

Myron W. Watkins, Chairman of the Committee on Price Research in the Petroleum Industry, has also made final revisions of his Committee's report. Although it too is in press, publication may be delayed until the report of the Committee on Prices in the Iron and Steel Industry has been brought up to date. The two reports may then be bound in one volume.

\section{PRODUCTION AND PRODUCTIVITY}

The National Bureau is happy to announce another grant by the Maurice and'Laura Falk Foundation to enlarge the scope of its studies of production and productivity. The new grant will make possible an investigation of production and productivity in nonmanufacturing industries since 1899 . The manuscript of the first volume of the series of studies-Production in Manufacturing Industries, I 899-1937-is being revised by Solomon Fabricant and will be submitted to the Board of Directors of the National Bureau for approval by the end of the year. 


\title{
The Statistical Pattern of Instalment Debt
}

\author{
OFFICERS \\ George Soule, Chairman \\ David FrIday, President \\ W. L. CRUM, Vice-President \\ Shepard Morgan, Treasurer \\ W. J. Carson, Executive Director \\ Martha Anderson, Editor \\ DIRECTORS AT LARGE
}

C. I. Barnard, President, New Fersey Bell Telephone Company

H. S. Dennison, Dennison Manufacturing Company

G. M. Harrison, Pres., Brotherhood of Railway and Steamship Clerks

O. W. KNauth, President, Associated Dry Gonds Corporation

H. W. LAIDLER, Executive Director, League for Industrial Democracy

L. C. Marshall, The American University

George O. May, Price, Waterhouse and Company

Shepard Morgan, Vice-President, Chase National Bank

G. E. Roberts, Economic Adviser, National City Bank

Beardsley Ruml, Treasurer, R. H. Macy and Company

George Soule, Director, The Labor Bureau, Inc.

N. I. Stone, Consulting Economist

\section{DIRECTORS BY UNIVERSITY APPOINTMENT}

W. L. $\mathrm{C}_{\mathrm{RUM}}$, Harvard

E. E. DaY, Cornell

Guy Stanton Ford, Minnesota

H. M. GRoves, Wisconsin

F. P. Graham, North Carolina

W. H. Hamilton, Yale

H. A. Millis, Chicago

A. H. Williams, Pennsylvania

\section{DIRECTORS APPOINTED BY OTHER ORGANIZATIONS}

F. M. FejKer, American Engineering Council

David Friday, American Economic Association

Lee Galloway, American Management Association

Malcolm Muir, National Publishers Association

W. W. Riefler, American Statistical Association

Matthew Woll, American Federation of Labor

\section{RESEARCH STAFF}

Wesley C. Mitchell, Director
A. F. Burns
F. C. MiLLS
Solomon FABricant
D. L. WICKENS
Milton FrJedman
LeO Wolman
Simon Kuznets
R. A. Youvig
F. R. MACAULAY
Eugen Átrschul, Associate

NATIONAL BUREAU OF ECONOMIC RESEARCH BULLETINS

Annual Subscription (5 issues), $\$ 2$; single copies, this issue, 50 cents 